
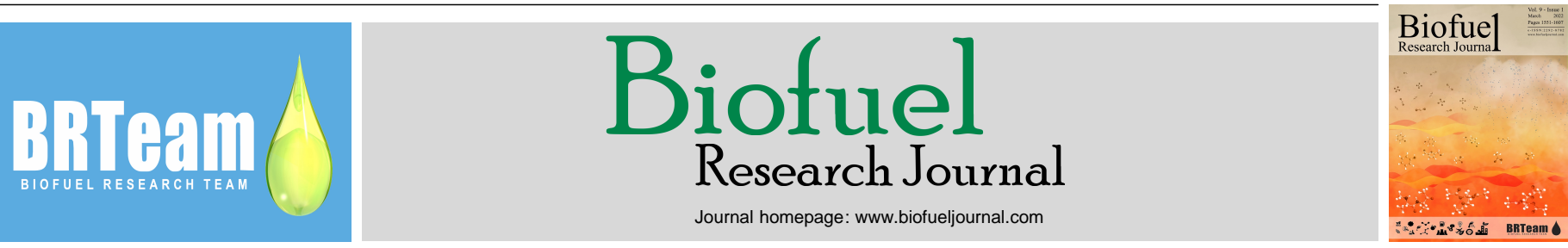

Review Paper

\title{
Exergy sustainability analysis of biomass gasification: a critical review
}

\author{
Hossein Shahbeig ${ }^{1}$, Alireza Shafizadeh ${ }^{2}$, Marc A. Rosen ${ }^{3}, *$ Bert F. Sels ${ }^{4}, *$
}

${ }^{1}$ Henan Province Forest Resources Sustainable Development and High-value Utilization Engineering Research Center, School of Forestry, Henan Agricultural University, Zhengzhou 450002, China.

${ }^{2}$ Department of Mechanical Engineering of Agricultural Machinery, Faculty of Agricultural Engineering and Technology, College of Agriculture and Natural Resources, University of Tehran, Karaj, Iran.

${ }^{3}$ Faculty of Engineering and Applied Science, University of Ontario Institute of Technology, Oshawa, Ontario, L1G 0C5, Canada.

${ }^{4}$ Center for Sustainable Catalysis and Engineering KU Leuven Celestijnenlaan 200 F, 3001 Heverlee, Belgium.

\section{HIGHLIGHTS}

$>$ The use of exergy methods for analyzing biomass gasification systems is critically reviewed. $>$ Bibliometric analysis identifies research themes in the exergy analysis of biomass gasification. $>$ Effects of process parameters on the exergy efficiency of biomass gasification are examined. $>$ The highest exergy efficiency is observed for a blend of $\mathrm{CO}_{2}$ and steam as a gasifying medium. $>$ The downdraft fixed-bed gasifier exhibits the highest exergy efficiency among biomass gasifiers.

\section{GRAPHICAL ABSTRACT}

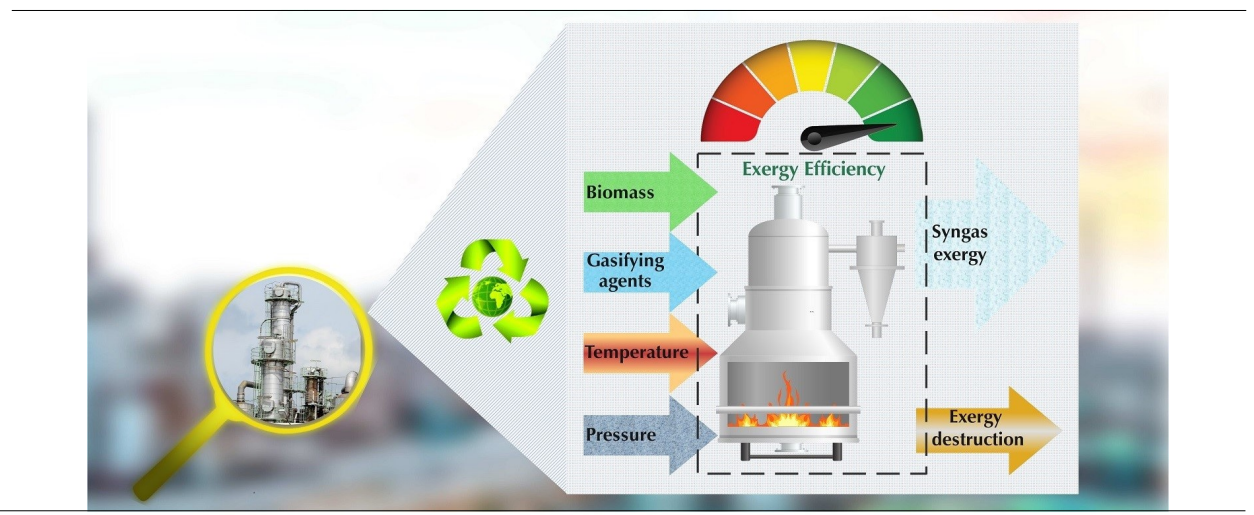

\begin{abstract}
Biomass gasification technology is a promising process to produce a stable gas with a wide range of applications, from direct use to the synthesis of value-added biochemicals and biofuels. Due to the high capital/operating costs of the technology and the necessity for prudent management of thermal energy exchanges in the biomass gasification process, it is important to use advanced sustainability metrics to ensure that environmental and other sustainability factors are addressed beneficially. Consequently, various engineering techniques are being used to make decisions on endogenous and exogenous parameters of biomass gasification processes to find the most efficient, viable, and sustainable operations and conditions. Among available approaches, exergy methods have attracted much attention due to their scientific rigor in accounting for the performance, cost, and environmental impact of biomass gasification systems. Therefore, this review is devoted to critically reviewing and numerically scrutinizing the use of exergy methods in analyzing biomass gasification systems. First, a bibliometric analysis is conducted to systematically identify research themes and trends in exergy-based sustainability assessments of biomass gasification systems. Then, the effects of biomass composition, reactor type, gasifying agent, and operating parameters on the exergy efficiency of the process are thoroughly investigated and mechanistically discussed. Unlike oxygen, nitrogen, and ash contents of biomass, the exergy efficiency of the gasification process is positively correlated with the carbon and hydrogen contents of biomass. A mixed gasifying medium $\left(\mathrm{CO}_{2}\right.$ and steam) provides higher exergy efficiency values. The downdraft fixed-bed gasifier exhibits the highest exergy efficiency among biomass gasification systems. Finally, opportunities and limitations of exergy methods for analyzing sustainability aspects of biomass gasification systems are outlined to guide future research in this domain.
\end{abstract}

(C) 2022 BRTeam. All rights reserved.

* Corresponding authors at:

E-mail address: marc.rosen@uoit.ca (Marc A. Rosen); bert.sels@ kuleuven.be (Bert F. Sels)

Please cite this article as: Shahbeig H., Shafizadeh A., Rosen M.A., Sels B.F. Exergy sustainability analysis of biomass gasification: a critical review. Biofuel Research Journal 33 (2022) 1592-1607. DOI: 10.18331/BRJ2022.9.1.5 


\section{Contents}

1. Introduction.

2. Bibliometric analysis.

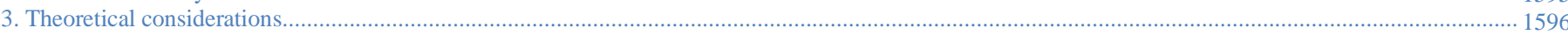

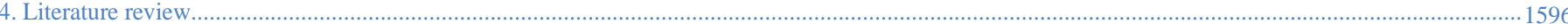

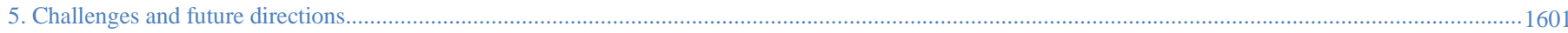

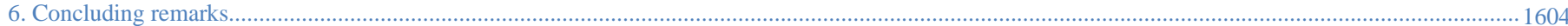

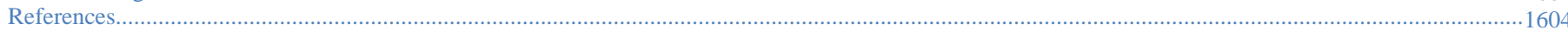

\begin{tabular}{|c|c|c|c|}
\hline \multicolumn{4}{|c|}{ Nomenclature } \\
\hline A & Ash content (wt\%) & $\dot{W}$ & Work rate $(\mathrm{kW})$ \\
\hline$c$ & Specific heat capacity $(\mathrm{kJ} / \mathrm{kg} \mathrm{K})$ & $x$ & Mass fraction (-) \\
\hline $\mathrm{C}$ & Carbon content (wt $\%$ ) & $y$ & Mole fraction (-) \\
\hline$D P$ & Depletion number (-) & $z$ & Height (m) \\
\hline$\dot{E}$ & Exergy rate $(\mathrm{kW})$ & Subscr & \\
\hline$e x$ & Specific exergy $(\mathrm{kJ} / \mathrm{kg})$ & 0 & Reference state \\
\hline$G$ & Gibbs free energy $(\mathrm{kJ} / \mathrm{mol})$ & $a$ & Air \\
\hline$g$ & Gravitational acceleration constant $\left(\mathrm{m}^{2} / \mathrm{s}\right)$ & $d$ & Destruction \\
\hline$h$ & Specific enthalpy (kJ/kg) & $e$ & Exit \\
\hline $\mathrm{H}$ & Hydrogen content (wt\%) & $j, m, l$ & Numerators \\
\hline$\dot{I P}$ & Exergetic improvement potential rate $(\mathrm{kW})$ & $i$ & Inlet \\
\hline$L H V$ & Lower heating value $(\mathrm{kJ} / \mathrm{kg})$ & tot & Total \\
\hline$\dot{m}$ & Mass flow rate $(\mathrm{kg} / \mathrm{s})$ & $v$ & Vapor \\
\hline$M$ & Molecular weight $(\mathrm{kg} / \mathrm{mol})$ & Supers & \\
\hline$n$ & Mole number & $p h$ & Physical \\
\hline $\mathrm{N}$ & Nitrogen content (wt\%) & $c h$ & Chemical \\
\hline $\mathrm{O}$ & Oxygen content (wt $\%$ ) & $k e$ & Kinetic \\
\hline$P$ & Absolute pressure $(\mathrm{kPa})$ & pe & Potential \\
\hline$\dot{Q}$ & Heat rate $(\mathrm{kW})$ & Greek & \\
\hline$R$ & Gas constant $(\mathrm{kJ} / \mathrm{kg} \mathrm{K})$ & $\omega$ & Humidity ratio (-) \\
\hline $\bar{R}$ & Universal gas constant $(8.314 \mathrm{~kJ} / \mathrm{mol} \mathrm{K})$ & $\varepsilon$ & Standard chemical exergy $(\mathrm{kJ} / \mathrm{mol})$ \\
\hline$s$ & Specific entropy $(\mathrm{kJ} / \mathrm{kg} \mathrm{K})$ & $\beta$ & Weighting factor (-) \\
\hline S & Sulfur content (wt $\%$ ) & $\phi$ & Universal exergy efficiency (\%) \\
\hline$S I$ & Sustainability index (-) & $\psi$ & Functional exergy efficiency $(\%)$ \\
\hline$T$ & Temperature $(\mathrm{K})$ & Abbre & \\
\hline V & Velocity $(\mathrm{m} / \mathrm{s})$ & sej & Solar emjoules \\
\hline
\end{tabular}

\section{Introduction}

Due to rapid population growth, industrialization, urbanization, and socioeconomic development, global energy consumption is continuously rising. As shown in Figure 1a, global energy consumption is expected to increase from 634.58 exajoule in 2020 to 935.04 exajoule in 2050 based on the data released by Energy Information Administration (EIA, 2019). Currently, fossil fuels such as oil, coal, and natural gas are the most frequently employed energy sources worldwide (Fig. 1b) (BP, 2020). However, fossil reserves are dwindling and, more importantly, their utilization is directly linked to climate change and ecosystem degradation. The growing environmental and other concerns regarding the excessive use of fossil fuel resources have stimulated research on developing and utilizing renewable energy technologies. Among various renewable energy resources, biomass energy (bioenergy) has gained increasing acceptance worldwide due to its ubiquitous, versatile, and compatible nature. According to projections of the International Energy Agency, biomass contribution to the global energy supply portfolio is expected to be around $10 \%$ by 2035 (Mohapatra and Singh, 2021). In addition, biomass-derived fuels have the potential to provide around $27 \%$ of global transportation fuels by 2050 (Mohapatra and Singh, 2021).

Several conversion routes have been investigated to produce bioenergy from various biomass feedstocks, including thermochemical (such as combustion, pyrolysis, gasification, liquefaction, and torrefaction), biochemical (such as composting, anaerobic digestion, and fermentation), and chemical (such as transesterification and esterification). Biomass thermochemical conversion routes have attracted increasing interest in recent decades for bioenergy production owing to their numerous benefits such as fast conversion, feedstock flexibility, product diversity, and higher efficiency (Soltanian et al., 2020). More importantly, thermochemical conversion processes play a pivotal role in biomass-based biorefinery systems. Among thermochemical methods, the gasification process has proven to be a promising approach to convert biomass into a combustible gas (syngas), condensable compounds (tar), and solid residue (biochar) at temperatures in the range of 600-1500 ${ }^{\circ} \mathrm{C}$ under the presence of a gasifying agent (normally air, steam, $\mathrm{O}_{2}, \mathrm{CO}_{2}$ ). The syngas, consisting of $\mathrm{H}_{2}, \mathrm{CH}_{4}, \mathrm{CO}$, and $\mathrm{CO}_{2}$, can be further processed to produce heat and electricity in power generation systems, to generate liquid transportation biofuels via Fischer-Tropsch synthesis, and to synthesize a wide spectrum of biofuels/biochemicals through biological processes (Sikarwar et al., 2016; Soltanian et al., 2022).

Despite the efficient, renewable, and eco-friendly nature of biomass gasification, this process requires high investment and operating costs. Also, this exothermic process is carried out at high temperatures while producing large amounts of thermal energy. Therefore, the thermal energy generated and consumed by biomass gasification needs to be effectively managed in order to improve its sustainability. Furthermore, various factors, including reactor type/configuration, biomass composition, particle size, gasification temperature, gasifying agent, gasifying agent/biomass ratio, catalyst type and quantity, and residence time, affect the performance 
a

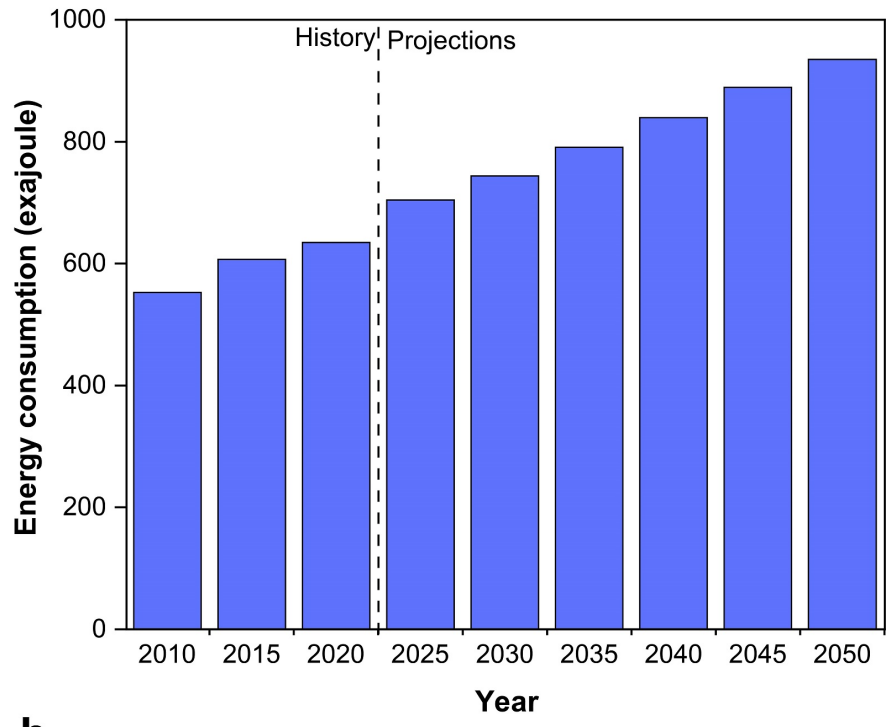

b

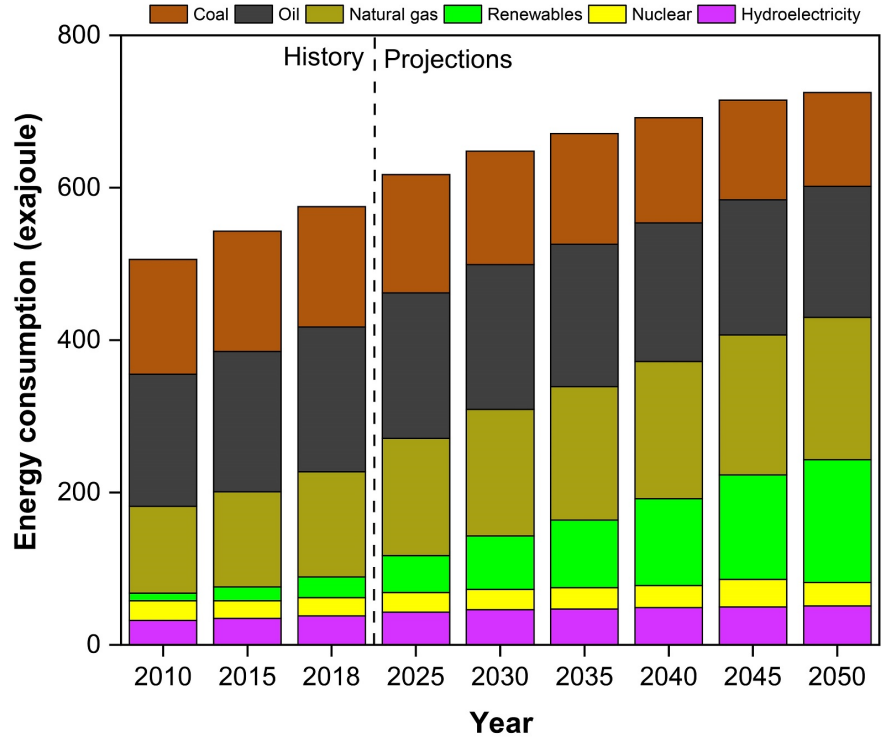

Fig. 1. (a) Global energy consumption outlook from 2010 to 2050 according to the Energy Information Administration (EIA, 2019) and (b) share of non-renewable and renewable energy sources to the global energy perspective from 2010 to 2050 according to British Petroleum (BP 2020).

of the biomass gasification process (Zhang et al., 2019). Accordingly, there is a need for advanced sustainability assessment indicators for the biomass gasification process to ensure its sustainability and to avoid significant environmental impacts. Various engineering frameworks, including technoeconomic analysis, thermodynamic-based measures (energy, emergy, and exergy-based approaches), and life cycle assessment, have been employed in past decades for measuring the sustainability aspects of biomass gasification technology.

Techno-economic analysis evaluates the economic feasibility and commercialization potential of a process by considering the total costs (capital and operating) and the potential incomes (Patel et al., 2016). Nevertheless, this sustainability assessment approach is not able to provide useful information concerning environmental and thermodynamic aspects of bioenergy systems (Cherp et al., 2018). Life cycle assessment is another useful tool to assess the potential environmental impacts (climate change, human health, ecosystem, and resource consumption) of bioenergy projects throughout their life cycles
(Ubando et al., 2019). However, this method lacks a standard procedure to specify system boundaries and interpret the obtained results (Wunderlich et al., 2021). Emergy analysis evaluates the sustainability of bioenergy systems by translating their inputs (human labor, money, natural resource, and services) into solar energy equivalents known as solar emjoules (sej). Selection of the proper transformity values to express all flows is the most challenging step in conducting emergy analysis (Tabatabaei and Aghbashlo, 2020). Energy analysis, based on the first law of thermodynamics, is the most widely used approach in the energy assessment of bioenergy systems. Despite the commonality of energy analysis, it does not necessarily lead to reliable decision-making because it disregards energy quality.

The exergy concept and exergy methods stemming from it have attracted much attention among available approaches, in part because its scientific rigor provides an opportunity to account for resource use (Grubb and Bakshi, 2011). This promising methodology effectively resolves the shortcomings of energy analysis by simultaneously measuring the quality and quantity of energy flows (Reyes et al., 2021). Exergy can also fairly weigh the work potential of material flows. In simple terms, exergy quantifies the maximum useful work obtainable from an energy or material flow when it is brought to equilibrium with a reference state by reversible processes (Aghbashlo and Rosen, 2018a). By conducting exergy analysis, the location, quantity, and source of thermodynamic inefficiencies (exergy destructions and losses) of bioenergy systems can be determined (Mahian et al., 2020). Given the direct relationship between resource conservation/ depletion and exergy destruction (as shown in Figure 2), exergy analysis can reliably measure the viability and sustainability of bioenergy systems. Additionally, the exergy concept can be extended by integrating it with economic and environmental factors and constraints (Aghbashlo and Rosen, 2018b).

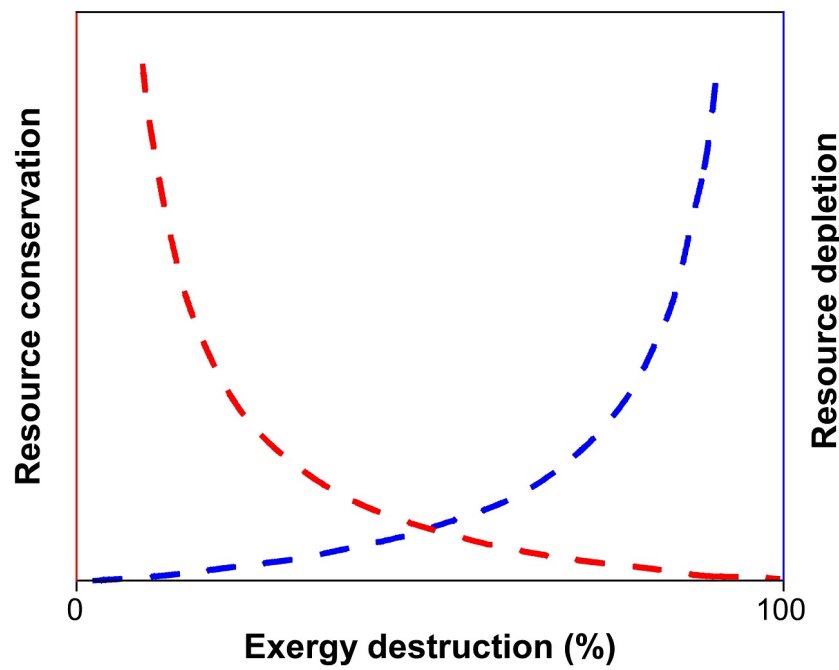

Fig. 2. The relationship between resource conservation and resource depletion with its exergy destruction. Adopted from Soltanian et al. (2022).

Due to the appealing features of the exergy concept, it has been increasingly used by researchers to assess the sustainability aspects of biomass gasification technology. The present review aims to critically review and numerically scrutinize the use of exergy analysis in investigating biomass gasification systems. In addition, a bibliometric analysis is conducted to systematically identify research themes and trends in exergy-based sustainability assessments of biomass gasification systems. To the best of the authors' knowledge, no comprehensive review has been reported on the advancement of and existing issues associated with applying exergy analysis to biomass gasification systems. Table 1 summarizes the key review papers dealing with exergy analysis of biomass gasification systems and points out the topics covered, further highlighting the originality of the present review. 
Table 1.

Key review papers dealing with exergy analysis of biomass gasification systems.

\begin{tabular}{|c|c|c|c|c|c|c|}
\hline Reference & Exergy analysis & Bibliometric analysis & Data visualization & $\begin{array}{c}\text { Effect of operating } \\
\text { conditions }\end{array}$ & $\begin{array}{c}\text { Reactor } \\
\text { type/configuration }\end{array}$ & $\begin{array}{l}\text { Integration of gasification } \\
\text { with other processes }\end{array}$ \\
\hline Chen et al. (2020) & $\checkmark$ & $x$ & $x$ & $x$ & $\checkmark$ & $x$ \\
\hline Ptasinski (2008) & $\checkmark$ & $x$ & $x$ & $\checkmark$ & $x$ & $\checkmark$ \\
\hline Christopher and Dimitrios (2012) & $\checkmark$ & $x$ & $x$ & $x$ & $x$ & $x$ \\
\hline Abuadala and Dincer (2012) & $\checkmark$ & $x$ & $x$ & $x$ & $x$ & $x$ \\
\hline Ibrahim et al. (2018) & $\checkmark$ & $x$ & $x$ & $\checkmark$ & $x$ & $\checkmark$ \\
\hline Kalinci et al. (2009) & $\checkmark$ & $x$ & $x$ & $\checkmark$ & $\checkmark$ & $x$ \\
\hline Present review & $\checkmark$ & $\checkmark$ & $\checkmark$ & $\checkmark$ & $\checkmark$ & $x$ \\
\hline
\end{tabular}

\section{Bibliometric analysis}

Bibliometric analysis is a robust statistical method to quantitatively assess the relevant academic literature to identify the main research (i.e., research hotspots and trends) (Du et al., 2021; Ranjbari et al., 2022). To utilize this useful tool, an important step involves defining a suitable search protocol to obtain as many relevant papers as possible. In this regard, the following search string was designed here: ("gasification" AND "biomass" AND "exergy") AND ("synthetic gas" OR "syngas" OR "thermodynamics" OR "second law of thermodynamics" OR "irreversibility" OR "exergy destruction" OR "thermochemical conversion" OR "exergetic" OR "exergy efficiency"). The primary run of the search string within the article titles, abstracts, and keywords of the literature in the Scopus database returned 488 articles. To increase the reliability of the analysis, exclusion criteria were considered. Therefore, only peer-reviewed journal articles in English with no time-period limit were considered. This constraint led to a total of 375 articles remaining for further processing. In the next step, the remaining papers were completely screened based on their titles and abstracts to ensure the quality of the studied sample. As a result, a total of 365 eligible articles were selected for the bibliometric analysis. VOSviewer software (version 1.6.18) was employed to conduct the bibliometric analysis (van Eck and Waltman, 2010). The procedures for selecting and collecting articles are detailed in Table 2. Figure 3 displays the publication trend of exergy-based sustainability assessments of biomass gasification systems from 2005 to 2021. The number of studies using exergy for analyzing biomass gasification systems is observed to have grown significantly over that time period, especially in the last few years.

Table 2.

Procedures for selecting and collecting articles.

\begin{tabular}{|c|c|}
\hline Step & Description \\
\hline Search string & $\begin{array}{l}\text { "gasification" AND "biomass" AND "exergy" } \\
\text { AND } \\
\text { "synthetic gas" OR "syngas" OR "thermodynamics" OR "second } \\
\text { law of thermodynamics" OR "irreversibility" OR "exergy } \\
\text { destruction" OR "thermochemical conversion" OR "exergetic" } \\
\text { OR "exergy efficiency" }\end{array}$ \\
\hline Database & Scopus \\
\hline Search within & Article titles, abstracts, and keywords \\
\hline Date of search & January 29, 2022 \\
\hline $\begin{array}{l}\text { Limitation in the year } \\
\text { of publications }\end{array}$ & No \\
\hline Inclusion criteria & Peer-reviewed journal articles in the English language \\
\hline Initial Result & 488 articles \\
\hline Exclusion criteria & $\begin{array}{l}\text { Book chapter, conference papers, editorial, note, letters, erratum, } \\
\text { and non-English documents }\end{array}$ \\
\hline Second result & 375 articles \\
\hline Screening stage & 10 articles were removed \\
\hline Eligible article & 365 articles \\
\hline
\end{tabular}

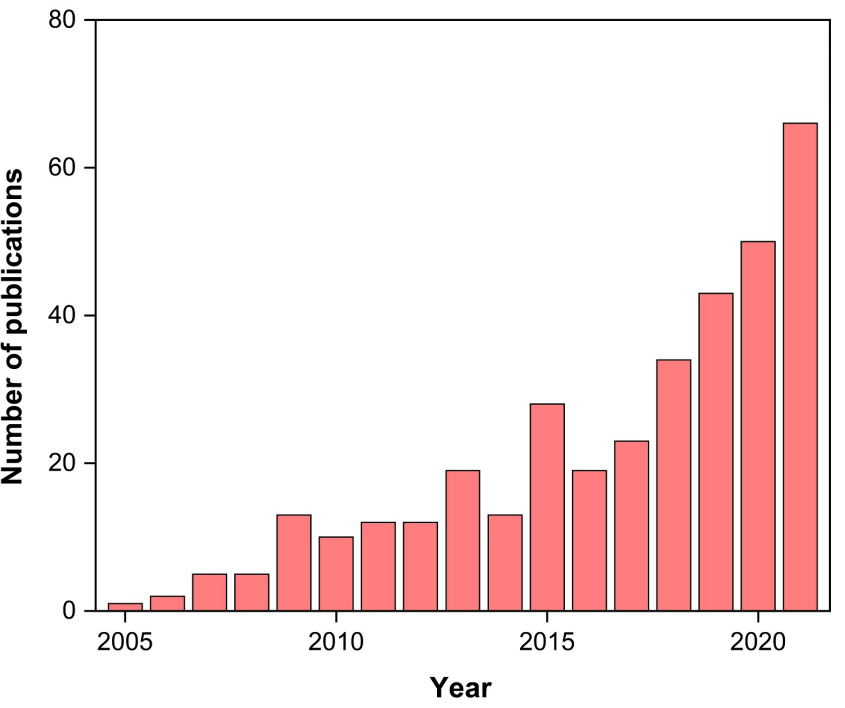

Fig. 3. Publication trend of exergy-based sustainability assessments of biomass gasification systems from 2005 to 2021 .

Keyword co-occurrence analysis was performed based on the keywords provided by authors, which could effectively express the field and main idea of each research. This method helps identify research hotspots and frontiers within the context of the selected domain (Det Udomsap and Hallinger, 2020). Some amendments were conducted in keywords before analysis: (i) replacing the short form (abbreviations) of the terms with their full forms where applicable, (ii) merging singular and plural formats of the keywords, (iii) unifying writing style, and (vi) eliminating general words without clear meaning such as "article" and "literature review". Accordingly, the top 15 most frequent keywords (among 456 keywords within the database) are tabulated in Table 3. As can be seen, exergy analysis, gasification, and biomass are the three most frequently used keywords of the authors, with 164, 164, and 162 occurrences, respectively. The large difference between the total link strength (i.e., the total connection of the links each keyword has with others) of these three most prominent keywords and other items highlights the attractiveness of exergy sustainability analysis of biomass gasification system among researchers. The next most frequent keywords in exergy-based sustainability analysis of biomass gasification are as follows: gasifier, hydrogen, energy analysis, solid oxide fuel cell, exergoeconomic analysis, multi-objective optimization, and syngas. The focus of these keywords in the selected domain is on the gasifier (as the main part of the biomass gasification process), product type (i.e., hydrogen or syngas), and economic assessment of the system.

The bibliographic coupling clustering technique was performed based on the reference numbers that each article cited to define a reliable map of 
Table 3 .

Top 15 most frequently occurring keywords in the eligible articles.

\begin{tabular}{lccc}
\hline Keyword & Total link & Total link strength & Occurrences \\
\hline Exergy analysis & 124 & 681 & 164 \\
Gasification & 124 & 677 & 164 \\
Biomass & 125 & 702 & 162 \\
Gasifier & 84 & 250 & 64 \\
Hydrogen & 80 & 268 & 59 \\
Energy analysis & 59 & 242 & 51 \\
Solid oxide fuel cell & 61 & 195 & 47 \\
Exergoeconomic analysis & 52 & 191 & 44 \\
Multi-objective optimization & 58 & 157 & 37 \\
Syngas & 63 & 152 & 36 \\
Exergy efficiency & 50 & 119 & 34 \\
Combined heat and power & 40 & 105 & 25 \\
Irreversibility & 42 & 91 & 23 \\
Carbon capture & 40 & 79 & 21 \\
Solar energy & 36 & 67 & 17 \\
\hline
\end{tabular}

the emergent research themes in the domain (Ranjbari et al., 2021). As shown in Figure 4, the four major research hotspots constituting the research field of exergy sustainability analysis of biomass gasification systems based on 375 articles were identified as follows: (1) integrating solid oxide fuel cell/organic Rankine cycle with biomass gasification systems and using exergy analysis and its extensions for their analysis, (2) thermodynamic analysis of biomass gasification systems consolidated with combined heat and power and combined cooling, heating, and power plants, (3) sustainability aspects analysis of hydrogen production from biomass gasification, and (4) effect of operating parameters on thermodynamic analysis of lignocellulosic biomass gasification.

\section{Theoretical considerations}

The most important equations used in exergy-based sustainability analyses of the biomass gasification process are tabulated in Table 4. In analyses, the exergetic contents of all the streams involved in the process should first be determined using the tabulated equations. Then, some dimensional/dimensionless exergetic indices should be calculated for the main components of the process and the overall system for comparison purposes.

\section{Literature review}

The gasification process converts organic compounds of biomass into a mixture of gases (mainly $\mathrm{CO}, \mathrm{H}_{2}, \mathrm{CO}_{2}, \mathrm{CH}_{4}$, and light hydrocarbons) in the presence of a gasifying agent at high temperatures (Situmorang et al. 2020). The gasification process mainly consists of four steps: drying, devolatilization, partial oxidation, and reduction. These involve numerous endothermic and exothermic reactions (water-gas shift, methanization, steam reforming, etc.) occurring simultaneously (La Villetta et al., 2017) The drying stage typically reduces the biomass moisture content to below $15 \%$ at temperatures lower than $200^{\circ} \mathrm{C}$, while the devolatilization step $\left(350-600^{\circ} \mathrm{C}\right)$ decomposes the organic material (such as hemicellulose cellulose, and lignin) into volatile compounds and solid residues. In the oxidation zone, the volatiles and char are oxidized to $\mathrm{CO}, \mathrm{CO}_{2}$, and $\mathrm{H}_{2} \mathrm{O}$ via exothermic reactions at high temperatures, while the devolatilization products are transformed to $\mathrm{CO}, \mathrm{CH}_{4}$, and $\mathrm{H}_{2}$ in the reduction stage (Gao et al., 2020; Situmorang et al., 2020). In general, several factors, including biomass composition, operating conditions, and reactor type/configuration, affect the exergy efficiency of the exothermic biomass gasification process (Abuadala and Dincer, 2012). Figure 5 illustrates a principal component analysis of the most effective parameters on the exergy efficiency of biomass gasification. The carbon, nitrogen, and ash content of biomass significantly contribute to the first principal component, while the volatile

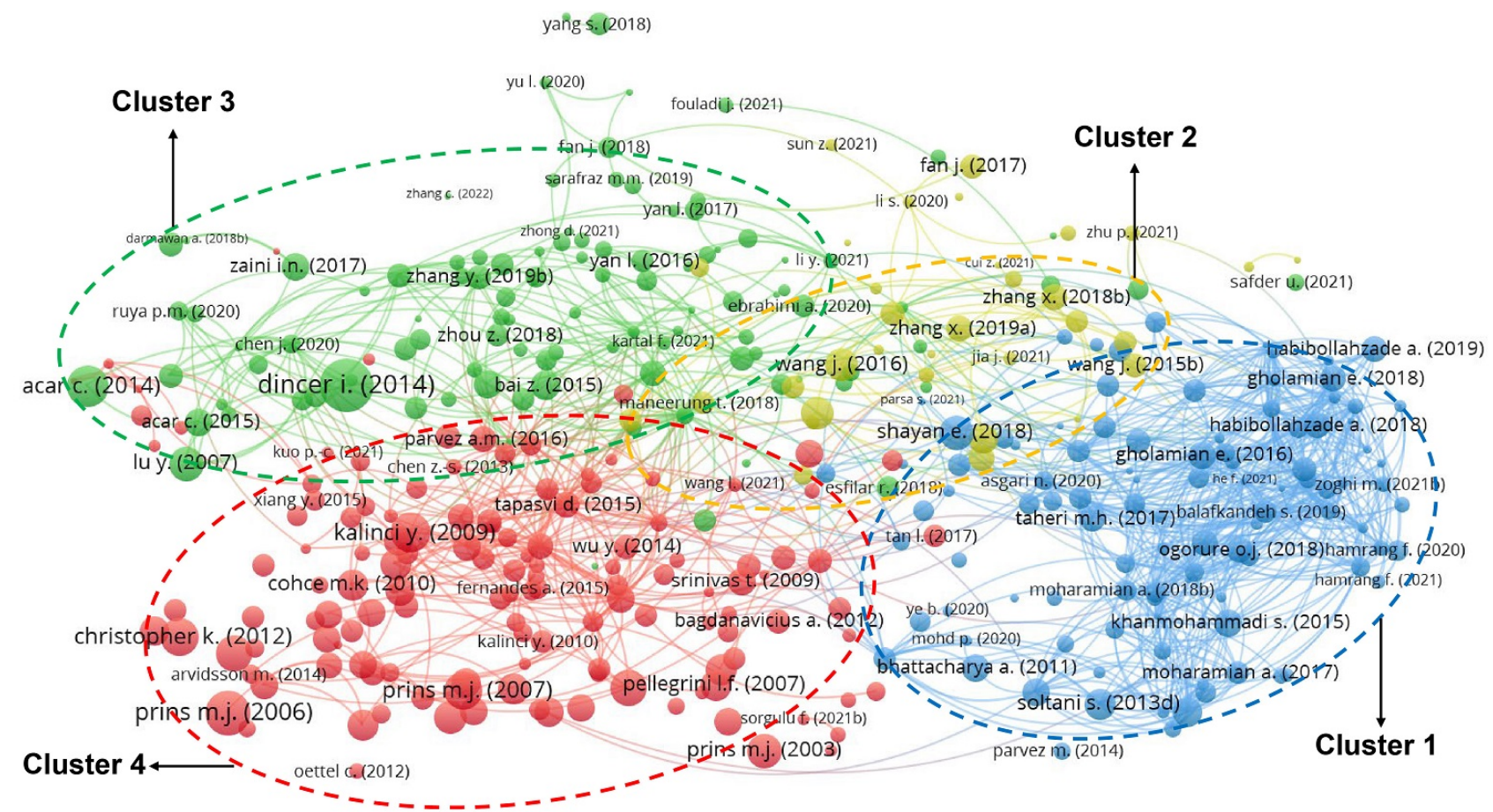

Cluster 1: Integrating solid oxide fuel cell/organic Rankine cycle with biomass gasification systems and using exergy analysis and its extensions for their analysis (N=101).

Cluster 2: Thermodynamic analysis of biomass gasification systems consolidated with combined heat and power and combined cooling heating and power plants ( $\mathrm{N}=36$ ).

Cluster 3: Sustainability aspects analysis of hydrogen production from biomass gasification $(\mathrm{N}=105)$.

Cluster 4: Effect of operating parameters on thermodynamic analysis of lignocellulosic biomass gasification (N=133).

Fig. 4. Bibliographic coupling clustering indicating the most important research themes in exergy sustainability analysis of biomass gasification systems (N is the number of articles in each cluster). 
Table 4.

Most important equations used in exergy analysis of biomass gasification processes.*

\begin{tabular}{|c|c|c|c|c|}
\hline \multirow{2}{*}{ Equation } & \multirow{2}{*}{ Application } & \multicolumn{3}{|c|}{ Item(s) in the equation } \\
\hline & & Notation(s) & Unit & Description \\
\hline \multicolumn{5}{|l|}{ General formulas: } \\
\hline$\sum_{i} \dot{m}_{i}=\sum_{e} \dot{m}_{e}$ & Mass balance of a component & $\dot{m}$ & $\mathrm{~kg} / \mathrm{s}$ & Mass flow rate \\
\hline$\sum_{i} \dot{Q}_{i}+\sum_{i} \dot{m}_{i} h_{i}=\dot{W}+\sum_{e} \dot{m}_{e} h_{e}$ & Energy balance of a component & $\begin{array}{c}\dot{Q} \\
\dot{W} \\
h\end{array}$ & $\begin{array}{l}\mathrm{kW} \\
\mathrm{kW} \\
\mathrm{kJ} / \mathrm{kg}\end{array}$ & $\begin{array}{l}\text { Heat rate } \\
\text { Work rate } \\
\text { Specific enthalpy }\end{array}$ \\
\hline$\sum_{i} \dot{Q}_{i}\left(1-\frac{T_{0}}{T_{i}}\right)+\sum_{i} \dot{m}_{i} e x_{i}=\dot{W}+\sum_{e} \dot{m}_{e} e x_{e}+\dot{E}_{d}$ & Exergy balance of a component & $\begin{array}{c}e x \\
\dot{E} \\
T \\
\dot{E}_{d}\end{array}$ & $\begin{array}{l}\mathrm{kJ} / \mathrm{kg} \\
\mathrm{kW} \\
\mathrm{K} \\
\mathrm{kW}\end{array}$ & $\begin{array}{l}\text { Total specific exergy } \\
\text { Exergy rate } \\
\text { Temperature } \\
\text { Exergy destruction rate }\end{array}$ \\
\hline$e x=e x^{p h}+e x^{c h}+e x^{k e}+e x^{p e}$ & Total specific exergy of a stream & $\begin{array}{l}e x^{p h} \\
e x^{c h} \\
e x^{k e} \\
e x^{p e}\end{array}$ & $\begin{array}{l}\mathrm{kJ} / \mathrm{kg} \\
\mathrm{kJ} / \mathrm{kg} \\
\mathrm{kJ} / \mathrm{kg} \\
\mathrm{kJ} / \mathrm{kg}\end{array}$ & $\begin{array}{l}\text { Specific physical exergy } \\
\text { Specific chemical exergy } \\
\text { Specific kinetic exergy } \\
\text { Specific potential exergy }\end{array}$ \\
\hline
\end{tabular}

\section{Physical exergy:}

\begin{tabular}{|c|c|c|c|c|}
\hline$e x^{p h}=h-h_{0}-T_{0}\left(s-s_{0}\right)$ & $\begin{array}{l}\text { Specific physical exergy of a } \\
\text { pure stream }\end{array}$ & $s$ & $\mathrm{~kJ} / \mathrm{kg} \mathrm{K}$ & Specific entropy \\
\hline$e x^{p h}=c\left(T-T_{0}-T_{0} \ln \left(\frac{T}{T_{0}}\right)\right)$ & $\begin{array}{l}\text { Specific physical exergy of a } \\
\text { mixed or even pure liquid stream }\end{array}$ & $c$ & $\mathrm{~kJ} / \mathrm{kg} \mathrm{K}$ & Specific heat capacity \\
\hline$e x^{p h}=c\left(T-T_{0}-T_{0} \ln \left(\frac{T}{T_{0}}\right)\right)+R T_{0} \ln \left(\frac{P}{P_{0}}\right)$ & $\begin{array}{l}\text { Specific physical exergy of a } \\
\text { mixed or even pure gaseous } \\
\text { stream }\end{array}$ & $\begin{array}{l}R \\
P\end{array}$ & $\begin{array}{l}\mathrm{kJ} / \mathrm{kg} \mathrm{K} \\
\mathrm{kPa}\end{array}$ & $\begin{array}{l}\text { Gas constant } \\
\text { Absolute pressure }\end{array}$ \\
\hline$c=\sum_{j=1}^{n} x_{j} c_{j}$ & $\begin{array}{l}\text { Specific heat capacity of a } \\
\text { mixed liquid/gaseous stream }\end{array}$ & $x$ & $(-)$ & Mass fraction \\
\hline$R=\frac{\bar{R}}{\sum_{j=1}^{n} y_{j} M_{j}}$ & $\begin{array}{l}\text { Gas constant of a mixed } \\
\text { liquid/gaseous stream }\end{array}$ & $\begin{array}{l}\bar{R} \\
y \\
M\end{array}$ & $\begin{array}{l}\mathrm{kJ} / \mathrm{mol} \mathrm{K} \\
(-) \\
\mathrm{kg} / \mathrm{mol}\end{array}$ & $\begin{array}{l}\text { Universal gas constant }(8.314) \\
\text { Mole fraction } \\
\text { Molecular weight }\end{array}$ \\
\hline $\begin{aligned} e x^{p h}=\left[c_{a}+\omega_{a} c_{v}\right]\left(T_{a}-\right. & \left.T_{0}\right)-T_{0}\left\{\left[c_{a}+\omega_{a} c_{v}\right] \ln \left(\frac{T_{a}}{T_{0}}\right)\right. \\
- & {\left.\left[R_{a}+\omega_{a} R_{v}\right] \ln \left(\frac{P_{a}}{P_{0}}\right)\right\}+T_{0}\left\{\left[R_{a}\right.\right.} \\
+ & \left.\omega_{a} R_{v}\right] \ln \left(\frac{1+1.6078 \omega_{a}}{1+1.6078 \omega_{0}}\right) \\
+ & \left.1.6078 \omega_{0} R_{a} \ln \left(\frac{\omega_{a}}{\omega_{0}}\right)\right\}\end{aligned}$ & $\begin{array}{l}\text { Specific physical exergy of the } \\
\text { air stream }\end{array}$ & $\begin{array}{l}C_{a} \\
C_{v} \\
R_{a} \\
R_{v} \\
T_{a} \\
P_{a} \\
\omega_{a} \\
\omega_{0}\end{array}$ & $\begin{array}{l}\mathrm{kJ} / \mathrm{kg} \mathrm{K} \\
\mathrm{kJ} / \mathrm{kg} \mathrm{K} \\
\mathrm{kJ} / \mathrm{mol} \\
\mathrm{kJ} / \mathrm{mol} \\
\mathrm{K} \\
\mathrm{kPa} \\
(-) \\
(-)\end{array}$ & $\begin{array}{l}\text { Specific heat capacity of air } \\
\text { Specific heat capacity of water } \\
\text { Gas constants of air } \\
\text { Gas constants of water vapor } \\
\text { Absolute temperature of air } \\
\text { Absolute pressure of air } \\
\text { Humidity ratio of air } \\
\text { Humidity ratio of reference state }\end{array}$ \\
\hline
\end{tabular}

Chemical exergy:

\begin{tabular}{|c|c|c|c|c|}
\hline$e x^{c h}=\sum_{j} \frac{1}{y_{j} M_{j}}\left(\sum_{j} y_{j} \varepsilon_{j}+\bar{R} T_{0} \sum_{j} y_{j} \ln \left(y_{j}\right)\right)$ & $\begin{array}{l}\text { Specific chemical exergy of a } \\
\text { gaseous stream }\end{array}$ & $\varepsilon_{j}$ & $\mathrm{~kJ} / \mathrm{mol}$ & $\begin{array}{l}\text { Standard chemical exergy of the } j^{\text {th }} \\
\text { stream }\end{array}$ \\
\hline$\varepsilon=-\Delta G+\sum_{\text {Product }} n_{m} \varepsilon_{m}-\sum_{\text {Reactant }} n_{l} \varepsilon_{l}$ & $\begin{array}{l}\text { Standard chemical exergy of an } \\
\text { inorganic compound }\end{array}$ & $\begin{array}{l}G \\
n\end{array}$ & $\begin{array}{l}\mathrm{kJ} / \mathrm{mol} \\
(-)\end{array}$ & $\begin{array}{l}\text { Gibbs free energy } \\
\text { Mole number }\end{array}$ \\
\hline $\begin{array}{c}e x^{c h}=100 *\{363.439[C]+1075.633[\mathrm{H}]-86.308[0]+4.14[\mathrm{~N}] \\
+190.798[\mathrm{~S}]-21.1[\mathrm{~A}]\}\end{array}$ & $\begin{array}{l}\text { Specific chemical exergy of both } \\
\text { solid and liquid organic } \\
\text { compounds }\end{array}$ & $\begin{array}{l}{[\mathrm{C}]} \\
{[\mathrm{H}]} \\
{[\mathrm{O}]} \\
{[\mathrm{N}]} \\
{[\mathrm{S}]} \\
{[\mathrm{A}]}\end{array}$ & $\begin{array}{l}\text { wt } \% \\
\text { wt } \% \\
\text { wt } \% \\
\text { wt } \% \\
\text { wt } \% \\
\text { wt } \%\end{array}$ & $\begin{array}{l}\text { Carbon content } \\
\text { Hydrogen content } \\
\text { Oxygen content } \\
\text { Nitrogen content } \\
\text { Sulfur content } \\
\text { Ash content }\end{array}$ \\
\hline
\end{tabular}


Table 4.

continued.

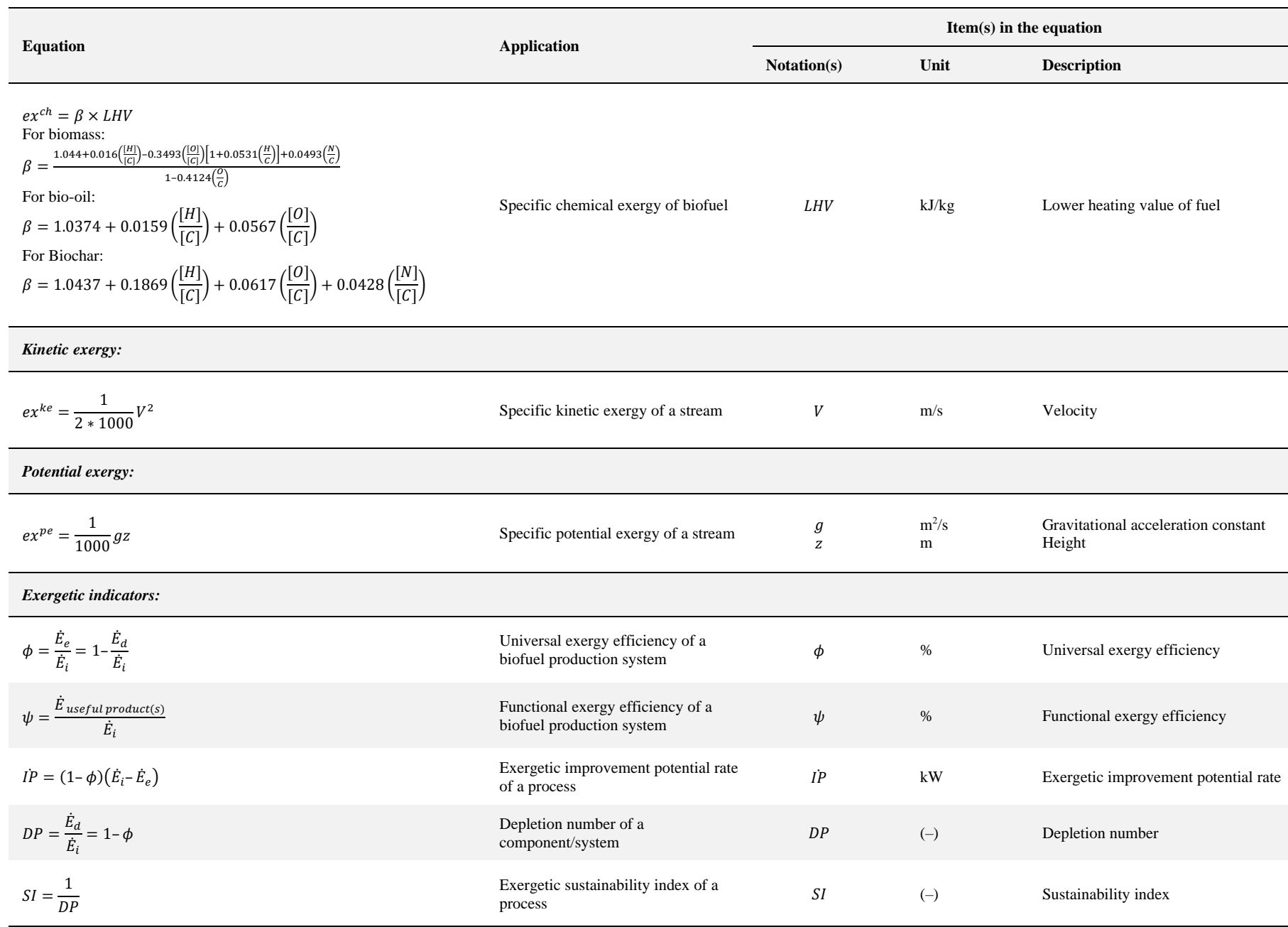

Subscripts:

$i$ : inlet stream, $e$ : exit stream, $d$ : destruction, 0 : reference state, $j, m, l$ : numerators, tot: total.

* Adapted from Soltanian et al. (2020 and 2022); Torres et al. (2020).

matter and fixed carbon of biomass mainly contribute to the second principal component (Fig. 5a). As shown in Figure 5b, the first principal component is mainly attributed to temperature and gasifying agent/biomass ratio, while pressure significantly contributes to the second principal component. The exergy efficiency is positively correlated with the carbon and hydrogen contents of biomass (Fig. 5a). The oxygen, nitrogen, and ash contents of biomass are negatively correlated with the exergy efficiency of the gasification process because of their negative effects on biomass chemical exergy. The exergy efficiency of the process is strongly correlated with temperature, showing the importance of this operating parameter in exergy analysis (Fig. $5 b)$.

Operating temperature is one of the most significant parameters in biomass gasification because of its direct effect on the devolatilization reactions as well as the process efficiency and syngas yield. Higher temperatures could marginally promote gasification reactions (i.e., water gas shift reaction, methane reforming, Boudouard, and cracking reactions), thus resulting in lower tar and char formation (Shahbaz et al., 2020). Note that the gasification process is commonly conducted at atmospheric pressure in order to discount capital and operating costs. However, pressurized regimes could enhance the gasification efficiency by suppressing tar formation and achieving easier recarbonization of $\mathrm{CO}_{2}$ (Ramos et al., 2018). The other important operating parameter is gasifying agent/biomass ratio which significantly affects the resultant syngas composition and its calorific value (La Villetta et al., 2017).

Figure 6 depicts a contour diagram indicating the relationship between the main operating conditions of biomass gasification (i.e., operating temperature, pressure, and gasifying agent/biomass) and exergy efficiency. Higher exergy efficiency values are obtained at temperatures, pressures, and gasifying agent/biomass ratios in the range of $850-1000{ }^{\circ} \mathrm{C}, 3.3-5.6$ atm, and 1.5-2, respectively. Generally, increasing gasification temperature promotes the water gas shift and steam reforming reactions, leading to higher $\mathrm{H}_{2}$ and $\mathrm{CO}$ concentrations while raising the process exergy efficiency. In addition, exothermic reactions such as $\mathrm{CO}_{2}$ and $\mathrm{CH}_{4}$ forming reactions are suppressed by increasing the gasification temperature owing to the promotion of Boudouard and methane reforming reactions, respectively (Echegaray et al., 2019). Like reaction temperature, the gasifying agent/biomass ratio markedly affects syngas composition and calorific value. Lower gasifying agent/biomass ratios enhance solid char and methane forming reactions, lowering the exergy efficiency of the process. Note that a higher gasifying agent/biomass ratio can provide a sufficient amount of oxidizing agents to complete primary and secondary decomposition reactions. Therefore, increasing the gasifying agent/biomass 
a

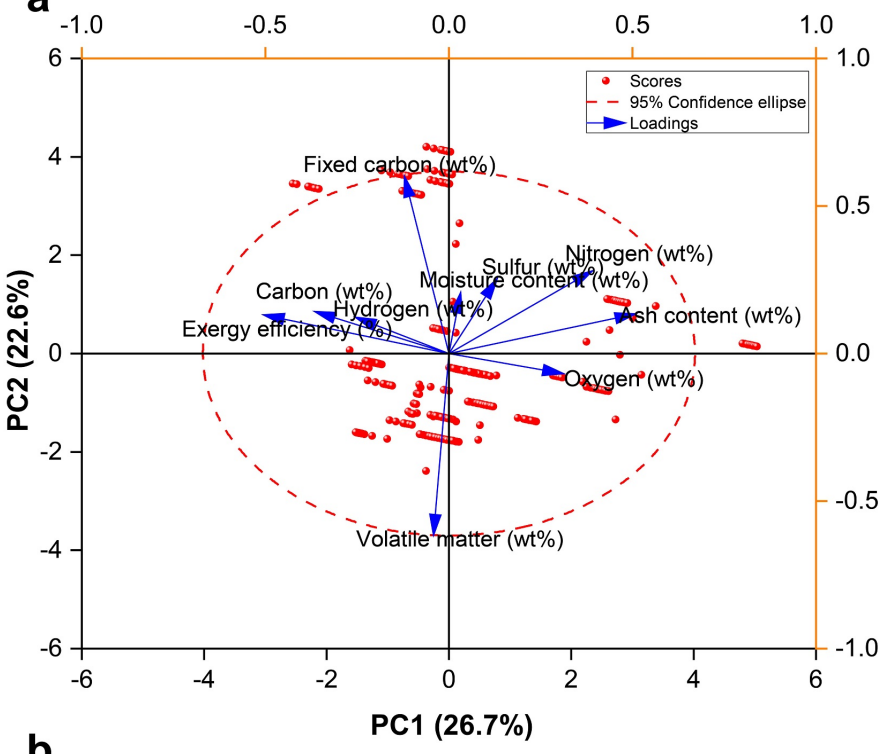

b

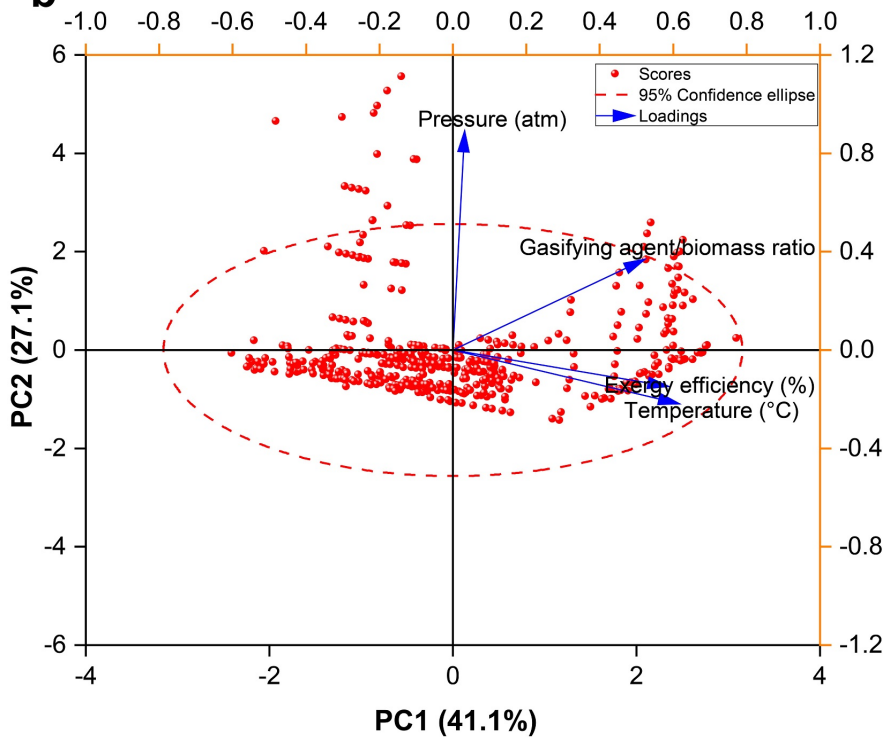

Fig. 5. Bibliographic Principal component analysis indicating the effects of biomass compositions (a) and operating conditions (b) on the exergy efficiency of the gasification process The dashed oval identified the confidence level of the collected data

Data collected from Abuadala et al. (2010); Abuadala and Dincer (2010); Beno Wincy et al, (2020); Bhattacharya et al. (2011); Cohce et al. (2011); Colpan et al. (2010); Couto et al. (2017); Cruz et al. (2017); Echegaray et al. (2019); Fryda et al. (2008); Gu et al. (2019); Heyne et al. (2013); Hosseinpour et al. (2020); Jia et al. (2015); Jurašćík et al. (2010); Kalinci et al. (2010); Kartal and Özveren (2021); Khoshgoftar Manesh and Jadidi (2020); Loha et al., 2011; Mahapatro et al., 2020; Manatura et al., 2017; Michailos et al., 2017; Mojaver et al., 2019; Nakyai et al., 2020; Parvez and Khan (2020); Patel et al. (2017); Prins et al. (2005); Ptasinski et al. (2007); Puadian et al. (2014); Reyes et al. (2021); Rupesh et al. (2020); Song et al. (2013); Sues et al. (2010); Tang et al. (2016); Thamavithya et al. (2012); van der Heijden and Ptasinski (2012); Vitasari et al. (2011); Wu et al. (2014 and 2020); Yan et al. (2006); Zhang et al. (2012); Zhao et al. (2021); Zhong et al. (2021)

ratio can improve the exergy efficiency of the biomass gasification process (Samimi et al., 2020).

Biomass composition plays a key role in the exergy analysis of biomass gasification by affecting the quantity and quality of the products. A contour diagram indicating the correlation between biomass composition (both ultimate

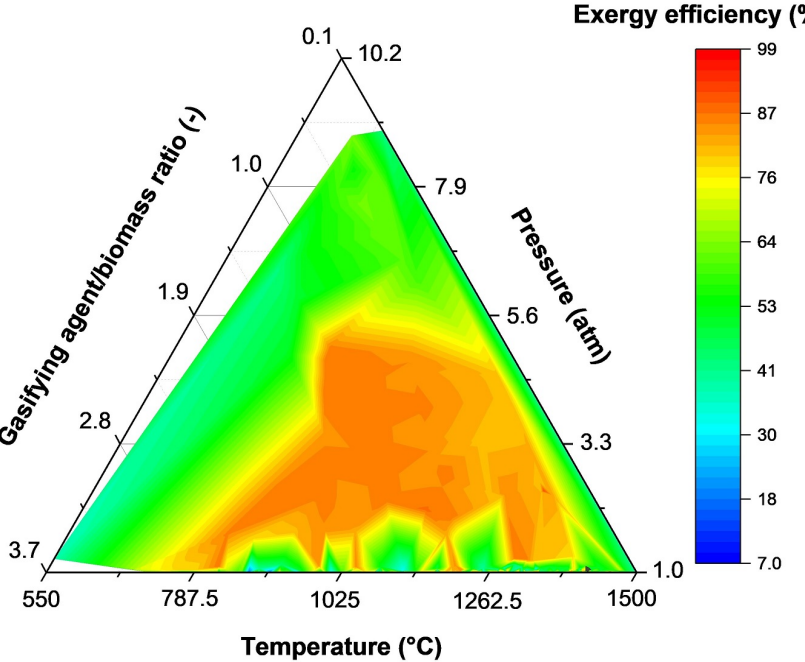

Fig. 6. Effect of operating parameters on the exergy efficiency of the biomass gasification process.

Data obtained from Abuadala et al. (2010); Abuadala and Dincer (2010); Beno Wincy et al. (2020); Fryda et al. (2008); Gu et al. (2019); Kartal and Özveren (2021); Loha et al. (2011); Manatura et al. (2017); Mojaver et al. (2019); Ptasinski et al. (2007); Rupesh et al. (2020); Song et al. (2013); Tang et al. (2016); Thamavithya et al. (2012); Vitasari et al. (2011); Wu et al. (2014); Zhao et al. (2021); Zhong et al. (2021).

and proximate) and exergy efficiency of biomass gasification is illustrated in Figure 7. Higher exergy efficiency values are obtained at carbon, hydrogen, and oxygen contents in the range of 45-55 wt $\%, 5.5-6.5 \mathrm{wt} \%$, and $30-40 \mathrm{wt} \%$, respectively. Carbon- and hydrogen-rich biomass feedstocks generally result in higher process exergy efficiency values by increasing the $\mathrm{CO}$ and $\mathrm{H}_{2}$ concentrations in the syngas and elevating its calorific value. Higher exergy efficiency values are observed for nitrogen contents in the range of $0.2-2 \mathrm{wt} \%$. It is noted that the amount of nitrogen should be minimized to avoid $\mathrm{NH}_{3}$ and $\mathrm{HCN}$ formation, reduce NOx emissions, prevent catalysis deactivation, and facilitate syngas cleaning and conditioning (Watson et al., 2018). Higher exergy efficiency values are obtained for volatile matter, moisture content, and ash content ranges of 60-70 wt $\%, 8-12 \mathrm{wt} \%$, and 2-6 wt $\%$, respectively. Generally, ash-rich biomass feedstocks result in a syngas having less exergy since the main gasification reactions such as water-gas shift, methanation, and steam reforming are suppressed at higher ash contents. Increasing the volatile matter of biomass can increase the concentration of organic vapors such as paraffinic and aromatic hydrocarbons in the syngas, resulting in an increased process exergy efficiency (Díaz González and Pacheco Sandoval, 2020). Note that higher moisture contents complicate the combustion stage in the biomass gasification process, leading to a syngas with less energy and, consequently, a reduced exergy efficiency. In addition, wet biomass lowers the oxidation temperature of gasification, resulting in incomplete decomposition of the hydrocarbons formed during the devolatilization stage (La Villetta et al., 2017).

The type of gasifying agent significantly affects biomass reactivity and syngas composition, thus impacting the exergy efficiency of the process. In order to achieve the desired syngas quality in downstream applications, oxygen, air, steam, $\mathrm{CO}_{2}$, or their mixtures can be applied in the gasification process. Table 5 summarizes the merits and limitations of the gasifying agents typically used in biomass gasification. Figure 8 shows the exergy efficiency derived from different gasifying agents and its kernel density distribution curve. Obviously, a mixture of $\mathrm{CO}_{2}$ and steam as a gasifying agent result in higher exergy efficiency values. This finding can be attributed to the role of steam in promoting the water-gas shift, steam reforming, and carbon oxidation reactions (Watson et al., 2018). In addition, $\mathrm{CO}_{2}$ can promote the Boudouard and reforming reactions, thereby enhancing the exergy efficiency. 
Exergy efficiency $(\%)$
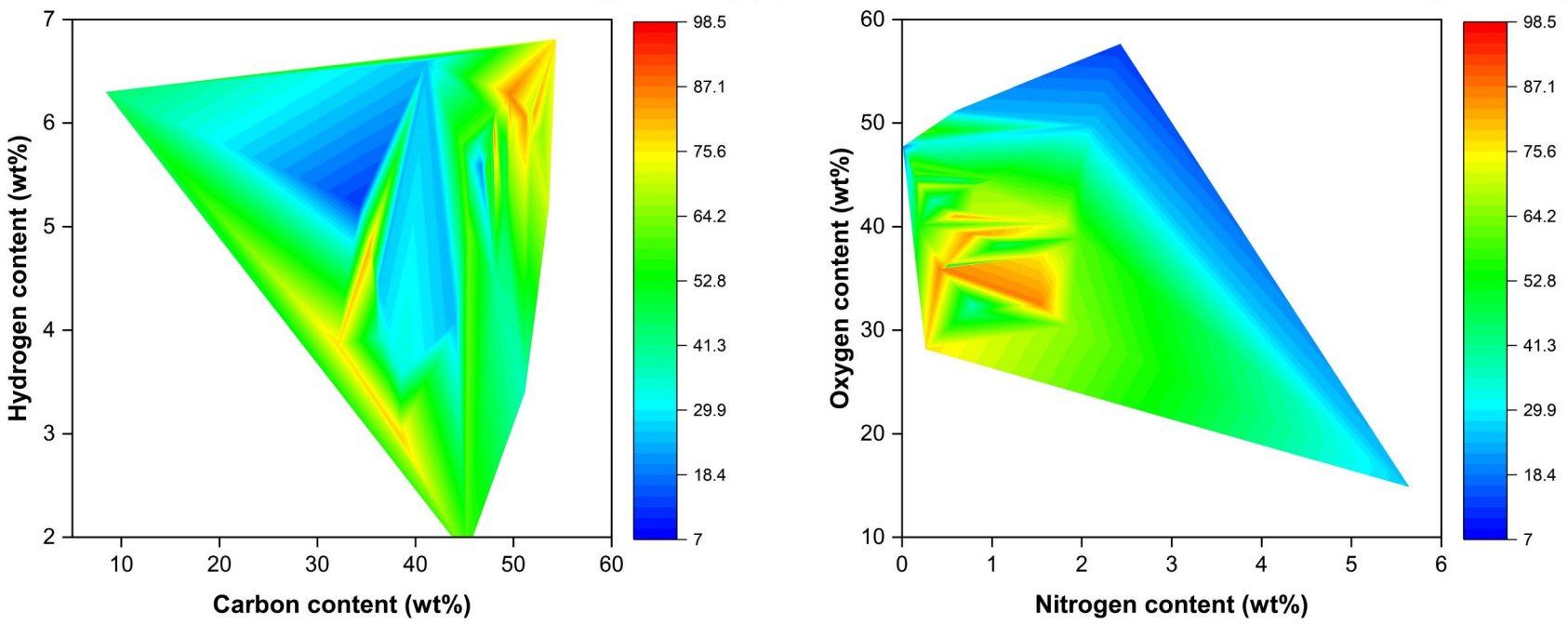

Exergy efficiency (\%)

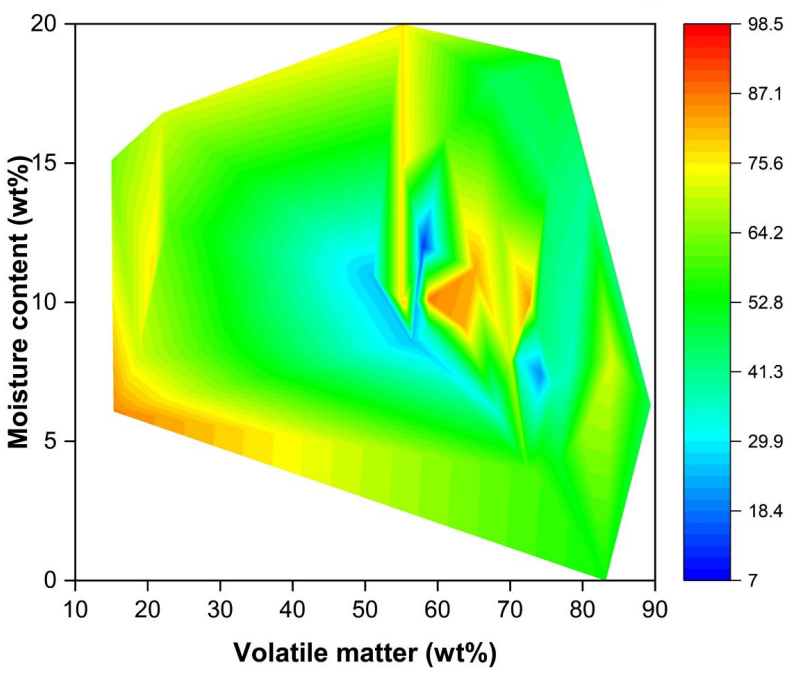

Exergy efficiency (\%)

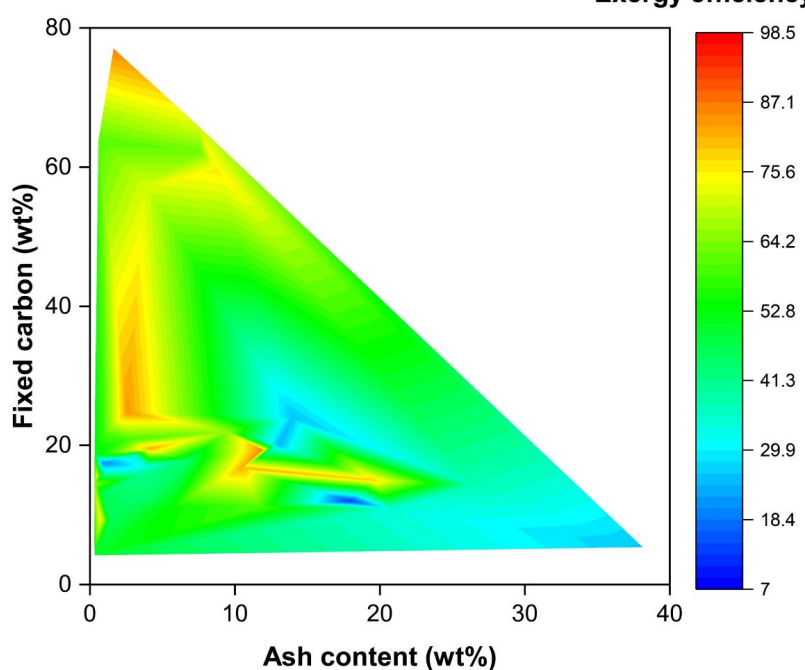

Fig. 7. Effect of biomass composition (both elemental and proximate) on the exergy efficiency of the gasification process.

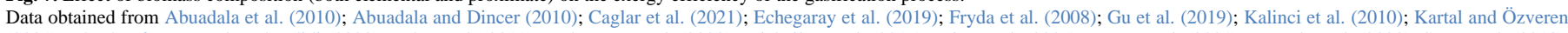

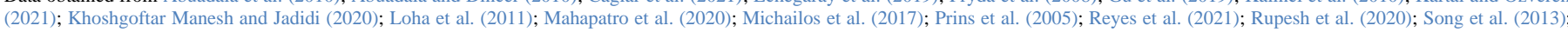
Tang et al. (2016); Wu et al. (2014).

Reactor type plays a major role in the quantity and quality of syngas during biomass gasification, thereby significantly affecting the exergetic features of the process. Typically, biomass gasification reactors are classified into fixedbed (downdraft and updraft), fluidized-bed (bubbling and circulating), entrained flow, rotary kiln, and plasma reactors (Ren et al., 2019). In updraft gasifiers (counter-current), the biomass is fed from the top, the gasifying agent is injected from the bottom, and the produced gas flows out from the top side of the reactor. In downdraft gasifiers (co-current), the biomass feeding strategy is as in the updraft case, the gasifying agent enters at the sides, and the syngas exits from the bottom side of the gasifier. Fixed bed reactors have been widely used for biomass gasification due to their advantages, such as high thermal efficiency, high carbon conversion, and the capacity to handle wet biomass. However, they suffer from high tar content, low feedstock flexibility, and low syngas yield (Ren et al., 2020).

Fluidized bed gasifiers require high flow rates to fluidize biomass particles, resulting in enhanced mixing capability, uniformity in temperature distribution in the reactor, and good reaction and heat transfer rates. In addition, entrained flow gasifiers operate at higher temperatures and pressures (20-70 bar) and require fine particles to produce high surface contact; such gasifiers are usually employed for residues and waste gasification (Sikarwar et al., 2016). Plasma gasifiers ionize syngas molecules using electric discharge to improve tar degradation and syngas quality in the absence of an oxidizing agent. These reactors are suitable for decomposing toxic organic wastes into elemental molecules due to their high operating temperatures (Heidenreich and Foscolo, 2015). Plasma gasifiers are more complex due to their high operating temperatures and related energy requirements. Table 6 summarizes the merits and limitations of various gasifier types. As depicted in Figure 9, the downdraft fixed-bed gasifier has the highest exergy efficiency among biomass gasification systems. This observation can be attributed to the excellent contact between the biomass and gasifying medium in the combustion stage, leading to the formation of high-quality syngas with low tar content (Wan et al., 2013; Ren et al., 2019). Circulating fluidized-bed and tubular gasifiers have relatively high exergy efficiencies because of their better heat and mass transfer features. 
Table 5 .

Advantages and disadvantages of selected gasifying agents.*

\begin{tabular}{|c|c|c|}
\hline Gasifying agent & Advantages & Disadvantages \\
\hline Air & $\begin{array}{l}\text { Simple operation } \\
\text { Mature technology } \\
\text { Simple heating process } \\
\text { Moderate char and tar content } \\
\text { Low soot production }\end{array}$ & $\begin{array}{l}\text { Lower } \mathrm{CO} \text { and } \mathrm{H}_{2} \text { concentrations } \\
\text { Lower efficiency and calorific value } \\
\text { of syngas } \\
\text { Higher contents of nitrogenous } \\
\text { compounds in syngas } \\
\text { Higher gas cleaning and separation } \\
\text { costs }\end{array}$ \\
\hline $\mathrm{O}_{2}$ & $\begin{array}{l}\text { Relatively mature technology } \\
\text { Negligible tar and char } \\
\text { formation } \\
\text { High-quality syngas } \\
\text { production by enhancing } \mathrm{H}_{2} \\
\text { and } \mathrm{CO} \\
\text { Small nitrogen dilution } \\
\text { Lower reaction temperature }\end{array}$ & $\begin{array}{l}\text { Higher capital and operating costs } \\
\text { Higher process complexity } \\
\text { Potential dangers associated with its } \\
\text { container }\end{array}$ \\
\hline $\mathrm{CO}_{2}$ & $\begin{array}{l}\text { Higher energetic content of } \\
\text { syngas } \\
\text { Negative } \mathrm{CO}_{2} \text { emissions } \\
\text { Higher gasification efficiency }\end{array}$ & $\begin{array}{l}\text { Higher char production } \\
\text { Longer reaction }\end{array}$ \\
\hline Steam & $\begin{array}{l}\text { Better carbon conversion } \\
\text { feature } \\
\text { Higher calorific value of } \\
\text { syngas } \\
\text { Higher concentrations of } \mathrm{H}_{2} \\
\text { and } \mathrm{CO} \text { in syngas } \\
\text { Higher efficiency }\end{array}$ & $\begin{array}{l}\text { Higher energy consumption } \\
\text { Potential of higher tar formation }\end{array}$ \\
\hline
\end{tabular}

* Source: Abdoulmoumine et al. (2015); Agu et al. (2019); Ahmad et al. (2016); Díaz González and Pacheco Sandoval (2020); Habibollahzade et al. (2021); Hanchate et al. (2021); Molino et al. (2018); Qin et al. (2012); Ren et al. (2019); Sansaniwal et al. (2017); Tinaut et al. (2008).

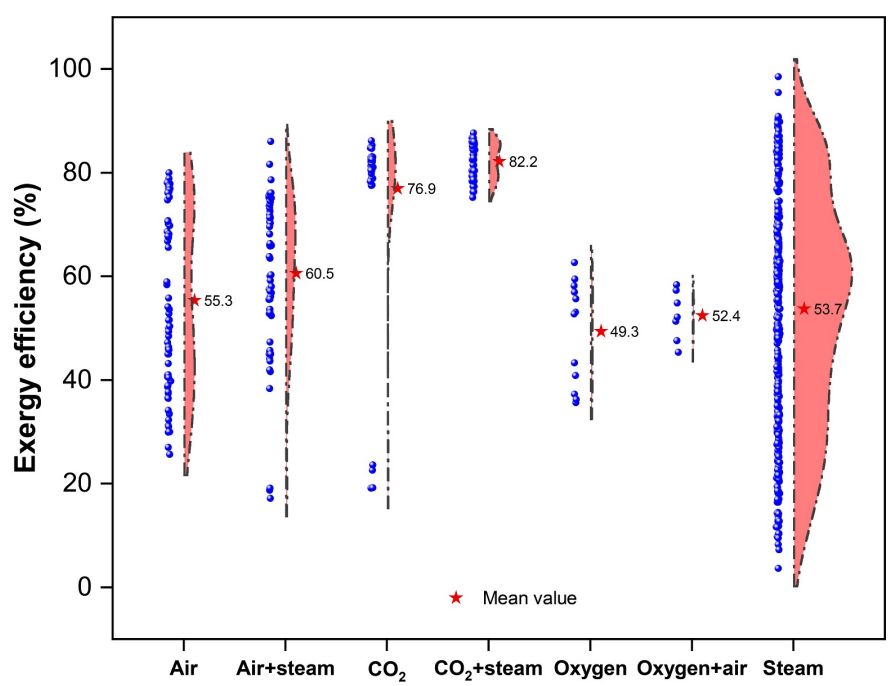

Fig. 8. Effect of gasifying agent on the exergy efficiency of biomass gasification.

Data obtained from Abuadala et al. (2010); Abuadala and Dincer (2010); Beno Wincy et al. (2020); Bhattacharya et al. (2011); Cohce et al. (2011); Colpan et al. (2010); Couto et al. (2017); Cruz et al. (2017); Echegaray et al. (2019); Fryda et al. (2008); Gu et al. (2019); Heyne et al. (2013); Hosseinpour et al. (2020); Jia et al. (2015); Juraščík et al. (2010); Kalinci et al. (2010); Kartal and Özveren (2021); Khoshgoftar Manesh and Jadidi (2020); Loha et al. (2011); Mahapatro et al. (2020); Manatura et al. (2017); Michailos et al. (2017); Mojaver et al. (2019); Nakyai et al. (2020); Parvez and Khan (2020); Patel et al. (2017); Prins et al. (2005); Ptasinski et al. (2007); Puadian et al. (2014); Reyes et al. (2021); Rupesh et al. (2020); Song et al. (2013); Sues et al. (2010); Tang et al. (2016); Thamavithya et al. (2012); van der Heijden and Ptasinski (2012); Vitasari et al. (2011); Wu et al. (2014 and 2020); Yan et al. (2006); Zhang et al. (2012); Zhao et al. (2021); Zhong et al. (2021).

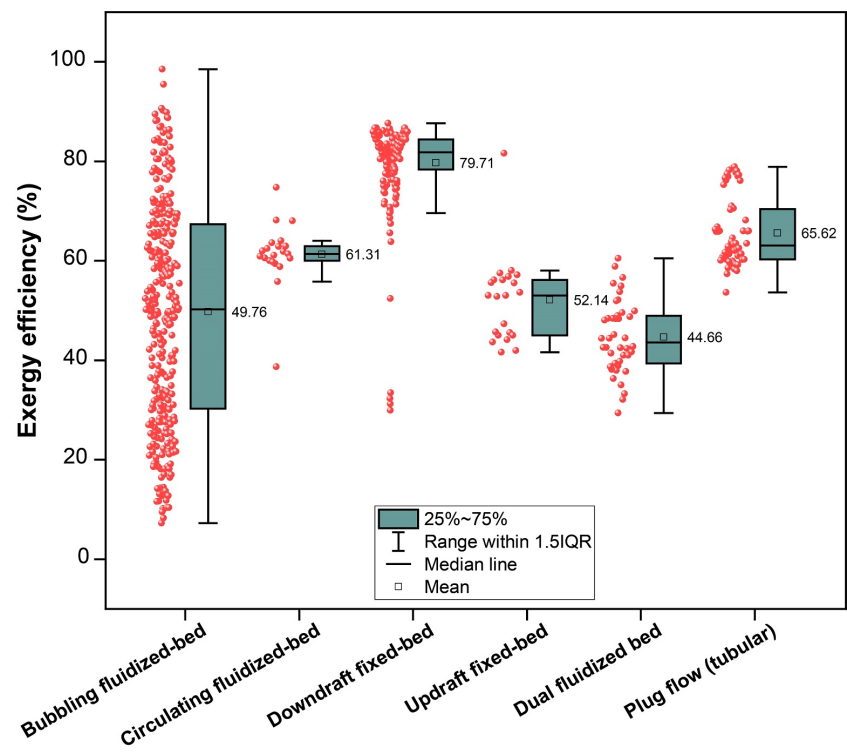

Fig. 9. Effect of reactor type on the exergy efficiency of biomass gasification Data obtained from Abuadala et al. (2010); Abuadala and Dincer (2010); Beno Wincy et al. (2020); Caglar et al. (2021); Couto et al. (2017); Echegaray et al. (2019); Hosseinpour et al (2020); Jia et al. (2015); Jurašćík et al. (2010); Kartal and Özveren (2021); Loha et al. (2011); Mahapatro et al. (2020); Manatura et al. (2017); Mojaver et al. (2019); Nakyai et al. (2020); Patel et al. (2017); Prins et al. (2005); Puadian et al. (2014); Reyes et al. (2021); Rupesh e al. (2020); Song et al. (2013); Sues et al. (2010); Tang et al. (2016); Thamavithya et al (2012); Vitasari et al. (2011); Wu et al. (2014); Zhao et al. (2021).

\section{Challenges and future directions}

Biomass gasification involves high-temperature biomass processing, with a large amount of thermal energy exchanged between the reactor and the surroundings. Accordingly, thermodynamic measures like exergy analysis can effectively assess the efficiency, viability, and sustainability of such high-energy exchange processes. Exergy methods can weigh different energy and material flows by determining their potentials to create work, thereby providing a sound decision-making basis for engineers and designers concerning biomass gasification processes. Despite the unique features of this sustainability assessment tool, it suffers from some inherent drawbacks like the high sensitivity of results to reference environment conditions (temperature, pressure, and chemical composition). More specifically, the choice of datum level significantly affects the rate of exergy destruction and exergy loss, thus impacting the dimensionless exergetic indicators. In addition, exergy analysis can only determine information about the internal irreversibility of biomass gasification systems while it alone is incapable of providing insights concerning economic and environmental aspects. Accordingly, advanced exergy-based analyses (e.g., exergoeconomic and exergoenvironmental) need to be applied in future research as complementary tools for investigating, evaluating, and optimizing biomass gasification. In addition, exergoeconoenvironmental methods that analyze energy systems from thermodynamic, economic, and environmental perspectives simultaneously can be used for investigating sustainability aspects of biomass gasification (Aghbashlo and Rosen, 2018a). The exergy concept does not account for non-physical energy flows like labor. This issue can be effectively resolved using the extended exergy method proposed by Sciubba (2019), in which all physical and non-physical streams are translated to an exergy basis (Joule).

Various dimensionless exergetic indicators have been defined in the literature, and these are useful, especially for comparison purposes. However, there is no universal agreement among researchers regarding the 
Table 6.

Comparison of biomass gasification systems.*

\begin{tabular}{lll}
\hline Reactor type & $\begin{array}{c}\text { Operating } \\
\text { temperature range }\end{array}$ & Advantages \\
\hline & & \\
& - & Applicable for various kinds of biomass \\
& feedstock \\
& - High thermal efficiency and carbon \\
& conversion \\
Downdraft fixed- & $-\begin{array}{l}\text { Favored when a clean syngas gas with a } \\
\text { bed }\end{array}$ & low content of tar and particulates is \\
& & desired \\
& $700-1200{ }^{\circ} \mathrm{C}$ & $-\begin{array}{l}\text { Favorable in small-scale power generation } \\
\text { plant }\end{array}$ \\
& &
\end{tabular}

Schematic diagram

\begin{tabular}{|c|c|c|}
\hline Updraft fixed-bed & $700-900{ }^{\circ} \mathrm{C}$ & $\begin{array}{l}\text { - Applicable for various kinds of biomass } \\
\text { feedstock } \\
\text { - High thermal efficiency and carbon } \\
\text { conversion } \\
\text { - Low pressure drops } \\
\text { - Low slag formation } \\
\text { - Low dust content at higher temperatures } \\
\text { - Simple and economic process } \\
\text { - Handling biomass with different particle } \\
\text { sizes }\end{array}$ \\
\hline
\end{tabular}

- Only dense feedstock is applicable

- Ash accumulation problem

- High temperature in the exhaust gas

Difficulties in handling feedstock with high moisture and ash contents

Non-uniform temperature distribution

- Difficulties in operation

- High content of tar in syngas

- Catalyst poisoning and deactivation

Low syngas yield and heating value

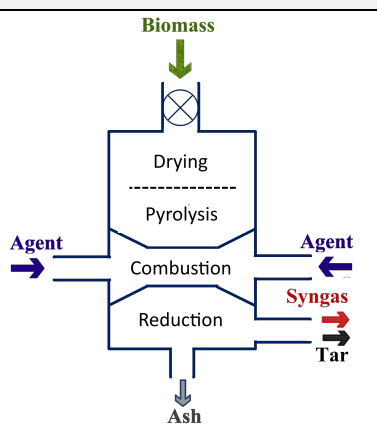

Low syngas yield and heating value

Long engine start-up time

- High tar and moisture in syngas

Difficulties in operation

Non-uniform temperature distribution

- Needing gas cleanup for downstream application

- Catalyst poisoning and deactivation

Increasing the probability of channeling and

bridging phenomen

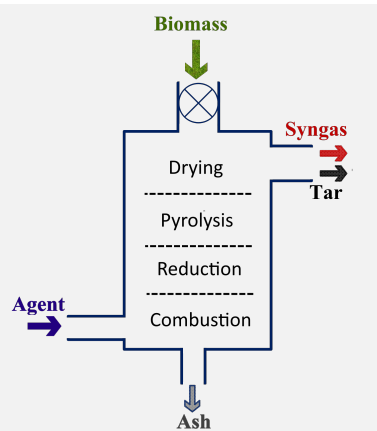

Applicable for various kinds of biomass feedstock

- High thermal efficiency and carbon

Cross draft fixed-

$\begin{array}{lll}\text { Cross draft fixed- } & \mathrm{Up} \text { to } 1300{ }^{\circ} \mathrm{C} & \text { - } \\ \text { bed } & \text { Simple configuration }\end{array}$

conversion

- High throughput and flexibility of syngas production

Low start-up time
- Low overall energy efficiency

High tar content in syngas

Poor reduction of $\mathrm{CO} 2$ concentration

- Non-uniform temperature distribution

- Difficulties in operation

- Catalyst poisoning and deactivation

- Low syngas yield and heating value

- Not suitable for large-scale

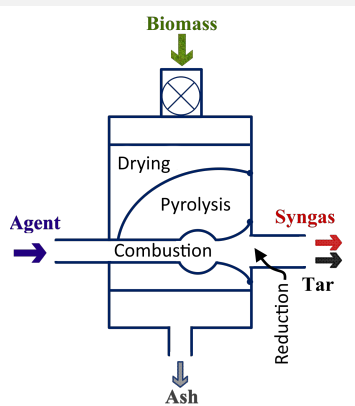

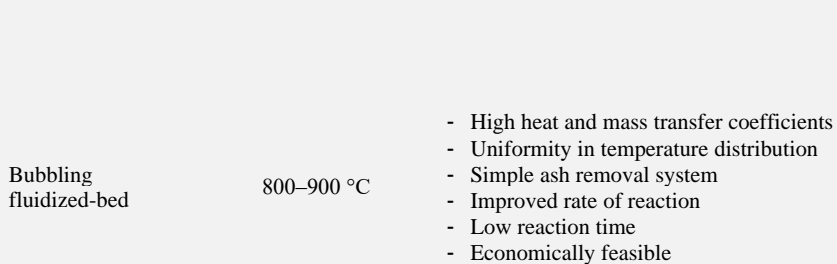

- Operational complexity

Eutectic formation at higher operating temperatures

Needing high velocity of gas flow

High particulate and tar contents in syngas

- Increasing the possibility of coalescence

phenomena

- Rapid char agglomeration
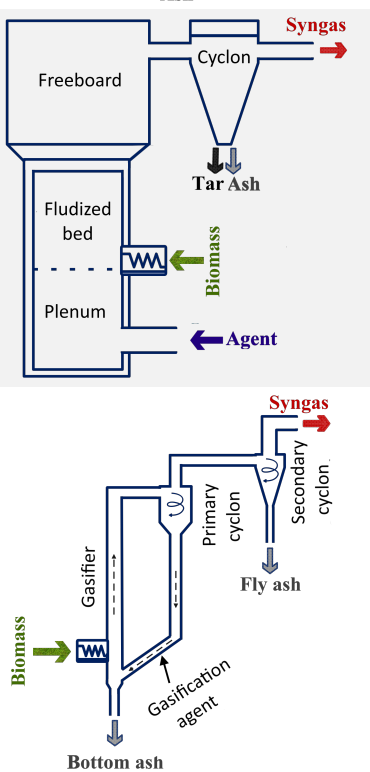

High heat and mass transfer coefficients Uniformity in temperature distribution

- Recycling of particulate matter

Circulating

$900-1200{ }^{\circ} \mathrm{C}$

- Possibility to employ a low-cost bed

fluidized-bed

material

- High throughput

- Capability to operate at higher pressures (suitable for gas turbine operating)

- Complex process control

Needing for high velocity of the gasifying medium

- High capital and operating costs

High particulate and tar contents in syngas

Bed particles agglomeration because of $\mathrm{Si}, \mathrm{K}$,

and $\mathrm{Ca}$ in biomass

* Source: de Lasa et al. (2011); Janajreh et al. (2013); Mishra and Upadhyay (2021); Motta et al. (2018); Ren et al. (2019); Sikarwar et al. (2017); Watson et al. (2018). 
Table 6.

continued.

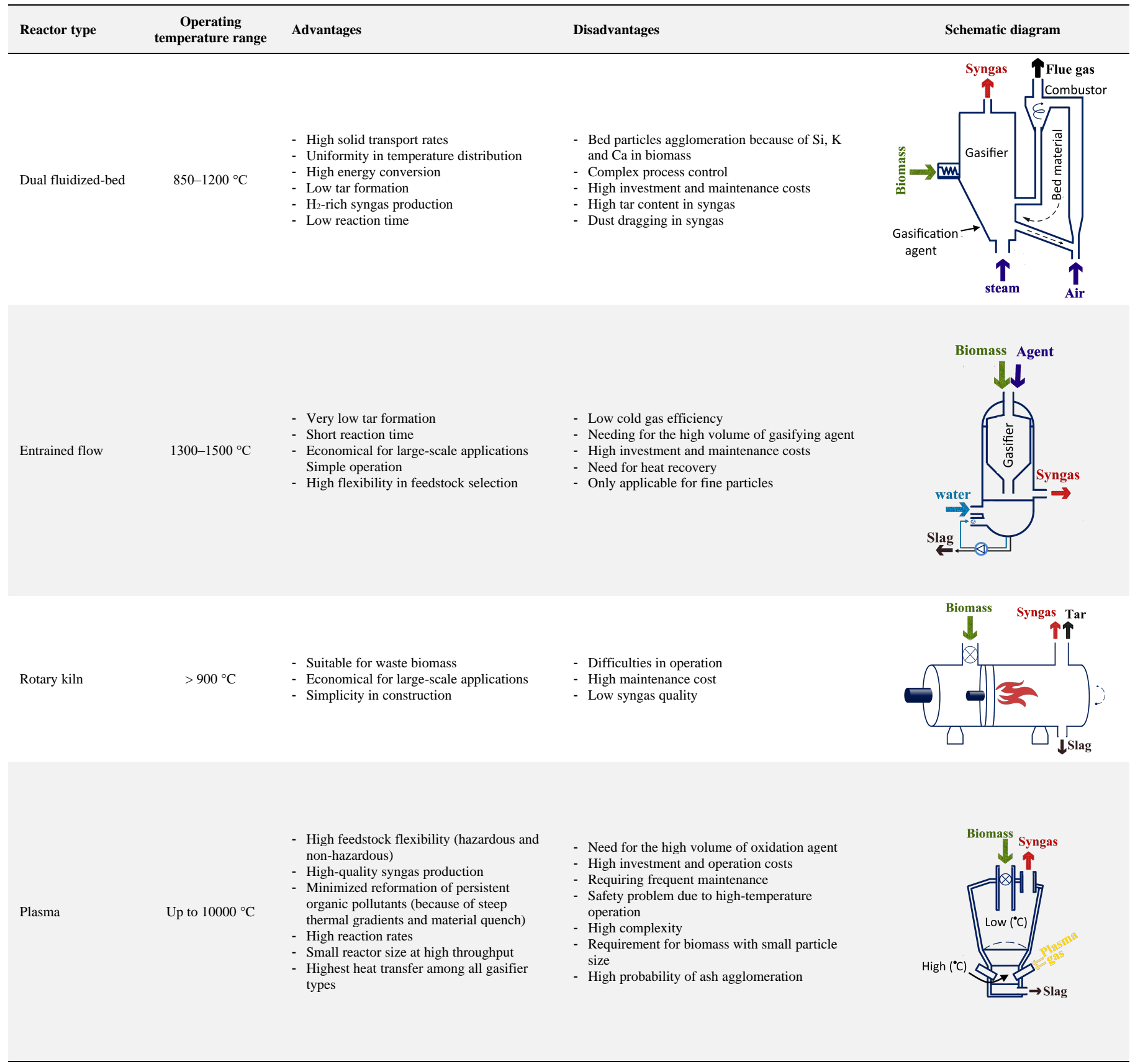

* Source: de Lasa et al. (2011); Janajreh et al. (2013); Mishra and Upadhyay (2021); Motta et al. (2018); Ren et al. (2019); Sikarwar et al. (2017); Watson et al. (2018).

definition of some dimensionless exergetic indicators. This issue might cause misinterpretations and misunderstandings of reported data and make comparisons of the results from different studies difficult. For example, two exergy efficiency definitions, i.e., universal and functional approaches, can be found in the literature. The universal exergy efficiency Indicates the degree of irreversibility and exergy loss in a thermodynamic system. This indicator cannot objectively and reliably measure the exergetic effectiveness of biomass gasification systems. However, the functional exergy efficiency, which evaluates the degree of productiveness and usefulness of a thermodynamic system, can be utilized accurately and meaningfully to compare biomass gasification systems. Overall, exergetic formulations for biomass gasification systems need to be harmonized and standardized in future research to make the results more interpretable and comparable. Furthermore, the contribution of chemical exergy to the total exergy of the streams involved in the biomass gasification process is significantly higher than physical exergy. Nevertheless, various theoretical, semi-theoretical, and empirical models with different accuracy and reliability levels have been used in the literature to calculate the chemical exergy content of biomass feedstocks and resultant products (particularly tar and char). This issue can negatively affect the accuracy and reliability of the obtained 
exergetic metrics. Developing robust models using machine learning and other advanced techniques can effectively address the challenge. In addition, the exergy content of byproducts of biomass gasification (i.e., biochar and tar), which are often ignored in the published papers, should be considered in future research.

Many studies have been published on exergy analyses of integrated biomass gasification systems, such as the combination of biomass gasification with solid oxide fuel cell/organic Rankine cycle/combined heat and power. However, less attention has been paid to exergetically evaluating the advanced biomass gasification systems used to produce liquid transportation biofuels via the catalytic Fischer-Tropsch process or mixed alcohols generation via catalytic fermentation. Another effective option to improve the exergetic performance of biomass gasification systems is to use renewable thermal energy and electricity sources like solar, wind, and geothermal energy. In addition, advanced heat integration methods like pinch analysis and self-heat recuperation technology can provide tools to enhance the exergy efficiency of biomass gasification by decreasing heating and cooling demands. Plasma gasification, pressurized gasification, and co-gasification of biomass with fossil fuels should also be exergetically evaluated in future investigations.

\section{Concluding remarks}

The present review numerically scrutinizes, systematically reviews, and critically discusses the effects of various parameters (i.e., operating conditions and biomass composition) on the exergy efficiencies and performance characteristics of biomass gasification systems. The main concluding remarks obtained from this review are as follows

- Unlike carbon and hydrogen contents of biomass, the exergy efficiency is negatively correlated with oxygen, nitrogen, and ash contents.

- The moisture content of biomass can markedly affect the exergetic performance of the gasification process.

- Among operating parameters, the reaction temperature is the most influential parameter on the exergy efficiency of biomass gasification. Gasifying agent/biomass ratio and operating pressure can markedly affect syngas composition.

- A mixture of $\mathrm{CO}_{2}$ and steam leads to the highest exergy efficiency among the investigated gasifying agents.

- The best reactor configuration for biomass gasification is the downdraft fixed-bed owing to it exhibiting the highest exergy efficiency value.

\section{References}

[1] Abdoulmoumine, N., Adhikari, S., Kulkarni, A., Chattanathan, S., 2015. A review on biomass gasification syngas cleanup. Appl. Energy 155, 294-307.

[2] Abuadala, A., Dincer, I., 2012. A review on biomass-based hydrogen production and potential applications. Int. J. Energy Res. 36, 415-455.

[3] Abuadala, A., Dincer, I., 2010. Efficiency evaluation of dry hydrogen production from biomass gasification. Thermochim. Acta 507-508, $127-134$

[4] Abuadala, A., Dincer, I., Naterer, G.F., 2010. Exergy analysis of hydrogen production from biomass gasification. Int. J. Hydrogen Energy 35, 4981-4990.

[5] Aghbashlo, M., Rosen, M.A., 2018a. Exergoeconoenvironmental analysis as a new concept for developing thermodynamically, economically, and environmentally sound energy conversion systems. J. Clean. Prod. 187, 190-204.

[6] Aghbashlo, M., Rosen, M.A., 2018b. Consolidating exergoeconomic and exergoenvironmental analyses using the emergy concept for better understanding energy conversion systems. J. Clean. Prod. 172, 696-708.

[7] Agu, C.E., Pfeifer, C., Eikeland, M., Tokheim, L.-A., Moldestad, B.M.E., 2019. Measurement and characterization of biomass mean residence time in an air-blown bubbling fluidized bed gasification reactor. Fuel 253, 1414-1423.

[8] Ahmad, A.A., Zawawi, N.A., Kasim, F.H., Inayat, A., Khasri, A., 2016. Assessing the gasification performance of biomass: A review on biomass gasification process conditions, optimization and economic evaluation. Renew. Sust. Energy Rev. 53, 1333-1347.
[9] Beno Wincy, W., Edwin, M., Joseph Sekhar, S., 2020. Energy and exergy evaluation of rice processing mills working with biomass gasifier in parboiling process. Fuel 259, 116255.

[10] Bhattacharya, A., Manna, D., Paul, B., Datta, A., 2011. Biomass integrated gasification combined cycle power generation with supplementary biomass firing: Energy and exergy based performance analysis. Energy 36, 2599-2610

[11] BP, 2020. Energy consumption worldwide from 2000 to 2018, with a forecast until 2050.

[12] Caglar, B., Tavsanci, D., Biyik, E., 2021. Multiparameter-based product, energy and exergy optimizations for biomass gasification. Fuel 303, 121208.

[13] Chen, J., Liang, J., Xu, Z., E, J., 2020. Assessment of supercritical water gasification process for combustible gas production from thermodynamic, environmental and techno-economic perspectives: A review. Energy Conv. Manag. 226, 113497.

[14] Cherp, A., Vinichenko, V., Jewell, J., Brutschin, E., Sovacool, B. 2018. Integrating techno-economic, socio-technical and political perspectives on national energy transitions: A meta-theoretical framework. Energy Res. Soc. Sci. 37, 175-190.

[15] Christopher, K., Dimitrios, R., 2012. A review on exergy comparison of hydrogen production methods from renewable energy sources. Energy Environ. Sci. 5, 6640.

[16] Cohce, M.K., Rosen, M.A., Dincer, I., 2011. Efficiency evaluation of a biomass gasification-based hydrogen production. Int. J. Hydrogen Energy 36, 11388-11398.

[17] Colpan, C.O., Hamdullahpur, F., Dincer, I., Yoo, Y., 2010. Effect of gasification agent on the performance of solid oxide fuel cell and biomass gasification systems. Int. J. Hydrogen Energy 35, 50015009

[18] Couto, N., Silva, V., Monteiro, E., Rouboa, A., 2017. Exergy analysis of Portuguese municipal solid waste treatment via steam gasification. Energy Conv. Manag. 134, 235-246.

[19] Cruz, P.L., Iribarren, D., Dufour, J., 2017. Exergy analysis of alternative configurations of a system coproducing synthetic fuels and electricity via biomass gasification, Fischer-Tropsch synthesis and a combined-cycle scheme. Fuel 194, 375-394.

[20] de Lasa, H., Salaices, E., Mazumder, J., Lucky, R., 2011. Catalytic Steam Gasification of Biomass: Catalysts, Thermodynamics and Kinetics. Chem. Rev. 111, 5404-5433.

[21] Det Udomsap, A., Hallinger, P., 2020. A bibliometric review of research on sustainable construction, 1994-2018. J. Clean. Prod. 254 120073.

[22] Díaz González, C.A., Pacheco Sandoval, L., 2020. Sustainability aspects of biomass gasification systems for small power generation. Renew. Sust. Energy Rev. 134, 110180

[23] Du, H.S., Xu, J., Li, Z., Liu, Y., Chu, S.K.W., 2021. Bibliometric mapping on sustainable development at the base-of-the-pyramid. J. Clean. Prod. 281, 125290

[24] Echegaray, M., García, D.Z., Mazza, G., Rodriguez, R., 2019. Airsteam gasification of five regional lignocellulosic wastes: Exergetic evaluation. Sustain. Energy Technol. Assess. 31, $115-123$

[25] EIA, 2019. Energy consumption worldwide from 1990 to 2020, with a forecast until 2050

[26] Fryda, L., Panopoulos, K.D., Karl, J., Kakaras, E., 2008. Exergetic analysis of solid oxide fuel cell and biomass gasification integration with heat pipes. Energy 33, 292-299.

[27] Gao, N., Kamran, K., Quan, C., Williams, P.T., 2020. Thermochemical conversion of sewage sludge: A critical review. Prog. Energy Combust. Sci. 79, 100843

[28] Grubb, G.F., Bakshi, B.R., 2011. Appreciating the role of thermodynamics in LCA improvement analysis via an application to titanium dioxide nanoparticles. Environ. Sci. Technol. 45, 45, 3054-3061

[29] Gu, H., Tang, Y., Yao, J., Chen, F., 2019. Study on biomass gasification under various operating conditions. J. Energy Inst. 92 $1329-1336$

[30] Habibollahzade, A., Ahmadi, P., Rosen, M.A., 2021. Biomass gasification using various gasification agents: Optimum feedstock 
selection, detailed numerical analyses and tri-objective grey wolf optimization. J. Clean. Prod. 284, 124718.

[31] Hanchate, N., Ramani, S., Mathpati, C.S., Dalvi, V.H., 2021. Biomass gasification using dual fluidized bed gasification systems: A review. J. Clean. Prod. 280, 123148.

[32] Heidenreich, S., Foscolo, P.U., 2015. New concepts in biomass gasification. Prog. Energy Combust. Sci. 46, 72-95.

[33] Heyne, S., Thunman, H., Harvey, S., 2013. Exergy-based comparison of indirect and direct biomass gasification technologies within the framework of bio-SNG production. Biomass Convers. Biorefin. 3, $337-352$

[34] Hosseinpour, J., Chitsaz, A., Liu, L., Gao, Y., 2020. Simulation of ecofriendly and affordable energy production via solid oxide fuel cell integrated with biomass gasification plant using various gasification agents. Renew. Energy 145, 757-771.

[35] Ibrahim, T.K., Mohammed, M.K., Awad, O.I., Abdalla, A.N., Basrawi, F., Mohammed, M.N., Najafi, G., Mamat, R., 2018. A comprehensive review on the exergy analysis of combined cycle power plants. Renew. Sust. Energy Rev. 90, 835-850.

[36] Janajreh, I., Raza, S.S., Valmundsson, A.S., 2013. Plasma gasification process: Modeling, simulation and comparison with conventional air gasification. Energy Convers. Manag. 65, 801-809.

[37] Jia, J., Abudula, A., Wei, L., Sun, B., Shi, Y., 2015. Thermodynamic modeling of an integrated biomass gasification and solid oxide fuel cell system. Renew. Energy 81, 400-410.

[38] Juraščík, M., Sues, A., Ptasinski, K.J., 2010. Exergy analysis of synthetic natural gas production method from biomass. Energy 35, 880-888.

[39] Kalinci, Y., Hepbasli, A., Dincer, I., 2010. Efficiency assessment of an integrated gasifier/boiler system for hydrogen production with different biomass types. Int. J. Hydrogen Energy 35, 4991-5000.

[40] Kalinci, Y., Hepbasli, A., Dincer, I., 2009. Biomass-based hydrogen production: A review and analysis. Int. J. Hydrogen Energy 34, 87998817

[41] Kartal, F., Özveren, U., 2021. A comparative study for biomass gasification in bubbling bed gasifier using Aspen HYSYS. Bioresour. Technol. Rep. 13, 100615

[42] Khoshgoftar Manesh, M.H., Jadidi, E., 2020. Conventional and advanced exergy, exergoeconomic and exergoenvironmental analysis of a biomass integrated gasification combined cycle plant. Energy Sources, Part A: Recovery Util. Environ. Eff. 1-22.

[43] La Villetta, M., Costa, M., Massarotti, N., 2017. Modelling approaches to biomass gasification: A review with emphasis on the stoichiometric method. Renew. Sust. Energy Rev. 74, 71-88.

[44] Loha, C., Chattopadhyay, H., Chatterjee, P.K., 2011. Thermodynamic analysis of hydrogen rich synthetic gas generation from fluidized bed gasification of rice husk. Energy 36, 4063-4071

[45] Mahapatro, A., Kumar, A., Mahanta, P., 2020. Parametric study and exergy analysis of the gasification of sugarcane bagasse in a pressurized circulating fluidized bed gasifier. J. Therm. Anal. Calorim. 141. $141,2635-2645$

[46] Mahian, O., Mirzaie, M.R., Kasaeian, A., Mousavi, S.H., 2020. Exergy analysis in combined heat and power systems: A review. Energy Convers. Manag. 226, 113467

[47] Manatura, K., Lu, J.H., Wu, K.T., Hsu, H.-T., 2017. Exergy analysis on torrefied rice husk pellet in fluidized bed gasification. Appl. Therm. Eng. 111, $1016-1024$.

[48] Michailos, S., Parker, D., Webb, C., 2017. A techno-economic comparison of Fischer-Tropsch and fast pyrolysis as ways of utilizing sugar cane bagasse in transportation fuels production. Chem. Eng. Res. Des. 118, 206-214.

[49] Mishra, S., Upadhyay, R.K., 2021. Review on biomass gasification: Gasifiers, gasifying mediums, and operational parameters. Mater. Sci. Energy Technol. 4, 329-340.

[50] Mohapatra, S.S., Singh, R.K., 2021. Production and characterization of the maximum liquid product obtained from co-pyrolysis of sugarcane bagasse and thermocol waste. Cellulose 28, 4223-4239.

[51] Mojaver, P., Jafarmadar, S., Khalilarya, S., Chitsaz, A., 2019. Study of synthesis gas composition, exergy assessment, and multi-criteria decision-making analysis of fluidized bed gasifier. Int. J. Hydrogen Energy 44, 27726-27740.
[52] Molino, A., Larocca, V., Chianese, S., Musmarra, D., 2018. Biofuels production by biomass gasification: A review. Energies 11.

[53] Motta, I.L., Miranda, N.T., Maciel Filho, R., Wolf Maciel, M.R. 2018. Biomass gasification in fluidized beds: A review of biomass moisture content and operating pressure effects. Renew. Sust. Energy Rev. 94, 998-1023.

[54] Nakyai, T., Patcharavorachot, Y., Arpornwichanop, A., Saebea, D. 2020. Comparative exergoeconomic analysis of indirect and direct bio-dimethyl ether syntheses based on air-steam biomass gasification with CO2 utilization. Energy 209, 118332.

[55] Parvez, M., Khan, O., 2020. Parametric simulation of biomass integrated gasification combined cycle (BIGCC) power plant using three different biomass materials. Biomass Convers. Biorefin. $10,803-812$

[56] Patel, M., Zhang, X., Kumar, A., 2016. Techno-economic and life cycle assessment on lignocellulosic biomass thermochemical conversion technologies: A review. Renew. Sust. Energy Rev. 53 1486-1499.

[57] Patel, V.R., Patel, D., Varia, N., Patel, R.N., 2017. Co-gasification of lignite and waste wood in a pilot-scale $(10 \mathrm{kWe})$ downdraft gasifier Energy 119, 834-844.

[58] Prins, M.J., Ptasinski, K.J., Janssen, F.J.J.G., 2005. Exergetic optimisation of a production process of Fischer-Tropsch fuels from biomass. Fuel Process. Technol. 86, 375-389.

[59] Ptasinski, K.J., 2008. Thermodynamic efficiency of biomass gasification and biofuels conversion. Biofuels Bioprod. Biorefin. 2, 239-253.

[60] Ptasinski, K.J., Prins, M.J., Pierik, A., 2007. Exergetic evaluation of biomass gasification. Energy 32, 568-574.

[61] Puadian, N., Li, J., Pang, S., 2014. Analysis of Operation Parameters in a Dual Fluidized Bed Biomass Gasifier Integrated with a Biomass Rotary Dryer: Development and Application of a System Model. Energies 7, 4342-4363.

[62] Qin, K., Jensen, P.A., Lin, W., Jensen, A.D., 2012. Biomass Gasification Behavior in an Entrained Flow Reactor: Gas Product Distribution and Soot Formation. Energy Fuels. 26, 5992-6002.

[63] Ramos, A., Monteiro, E., Silva, V., Rouboa, A., 2018. Co-gasification and recent developments on waste-to-energy conversion: A review. Renew. Sust. Energy Rev. 81, 380 -398.

[64] Ranjbari, M., Saidani, M., Shams Esfandabadi, Z., Peng, W., Lam S.S., Aghbashlo, M., Quatraro, F., Tabatabaei, M., 2021. Two decades of research on waste management in the circular economy: Insights from bibliometric, text mining, and content analyses. J. Clean. Prod. 314, 128009

[65] Ranjbari, M., Shams Esfandabadi, Z., Shevchenko, T., ChassagnonHaned, N., Peng, W., Tabatabaei, M., Aghbashlo, M., 2022. Mapping healthcare waste management research: Past evolution, curren challenges, and future perspectives towards a circular economy transition. J. Hazard. Mater. 422, 126724

[66] Ren, J., Cao, J.-P., Zhao, X.-Y., Yang, F.-L., Wei, X.-Y., 2019. Recent advances in syngas production from biomass catalytic gasification: A critical review on reactors, catalysts, catalytic mechanisms and mathematical models. Renew. Sust. Energy Rev. 116,109426

[67] Ren, J., Liu, Y.L., Zhao, X.Y., Cao, J.P., 2020. Methanation of syngas from biomass gasification: An overview. Int. J. Hydrogen Energy 45 , 4223-4243.

[68] Reyes, L., Abdelouahed, L., Campusano, B., Buvat, J.-C., Taouk, B. 2021. Exergetic study of beech wood gasification in fluidized bed reactor using $\mathrm{CO} 2$ or steam as gasification agents. Fuel Process. Technol. 213, 106664

[69] Rupesh, S., Muraleedharan, C., Arun, P., 2020. Energy and exergy analysis of syngas production from different biomasses through airsteam gasification. Front. Energy 14, 607-619.

[70] Samimi, F., Marzoughi, T., Rahimpour, M.R., 2020. Energy and exergy analysis and optimization of biomass gasification process for hydrogen production (based on air, steam and air/steam gasifying agents). Int. J. Hydrogen Energy 45, 33185-33197.

[71] Sansaniwal, S.K., Pal, K., Rosen, M.A., Tyagi, S.K., 2017. Recent advances in the development of biomass gasification technology: A 
comprehensive review. Renew. Sust. Energy Rev. 72, 363-384.

[72] Sciubba, E., 2019. Exergy-based ecological indicators: From ThermoEconomics to cumulative exergy consumption to Thermo-Ecological Cost and Extended Exergy Accounting. Energy 168, 462-476.

[73] Shahbaz, M., Al-Ansari, T., Inayat, M., Sulaiman, S.A., Parthasarathy, P., McKay, G., 2020. A critical review on the influence of process parameters in catalytic co-gasification: Current performance and challenges for a future prospectus. Renew. Sust. Energy Rev. 134, 110382

[74] Sikarwar, V.S., Zhao, M., Clough, P., Yao, J., Zhong, X., Memon, M.Z., Shah, N., Anthony, E.J., Fennell, P.S., 2016. An overview of advances in biomass gasification. Energy Environ. Sci. 9, 2939 -2977.

[75] Sikarwar, V.S., Zhao, M., Fennell, P.S., Shah, N., Anthony, E.J., 2017. Progress in biofuel production from gasification. Prog. Energy Combust. Sci. 61, 189-248

[76] Situmorang, Y.A., Zhao, Z., Yoshida, A., Abudula, A., Guan, G., 2020. Small-scale biomass gasification systems for power generation $(<200 \mathrm{~kW}$ class): A review. Renew. Sust. Energy Rev. 117, 109486.

[77] Soltanian, S., Aghbashlo, M., Almasi, F., Hosseinzadeh-Bandbafha, H., Nizami, A.S., Ok, Y.S., Lam, S.S., Tabatabaei, M., 2020. A critical review of the effects of pretreatment methods on the exergetic aspects of lignocellulosic biofuels. Energy Convers. Manag 212, 112792

[78] Soltanian, S., Kalogirou, S.A., Ranjbari, M., Amiri, H., Mahian, O., Khoshnevisan, B., Jafary, T., Nizami, A.-S., Gupta, V.K., Aghaei, S., Peng, W., Tabatabaei, M., Aghbashlo, M., 2022. Exergetic sustainability analysis of municipal solid waste treatment systems: A systematic critical review. Renew. Sust. Energy Rev. 156, 111975.

[79] Song, G., Chen, L., Xiao, J., Shen, L., 2013. Exergy evaluation of biomass steam gasification via interconnected fluidized beds. Int. J. Energy Research 37, 1743-1751.

[80] Sues, A., Juraščík, M., Ptasinski, K., 2010. Exergetic evaluation of 5 biowastes-to-biofuels routes via gasification. Energy 35, 996-1007.

[81] Tabatabaei, M., Aghbashlo, M., 2020. The critical role of advanced sustainability assessment tools in enhancing the real-world application of biofuels. Acta Innov. 67-73

[82] Tang, Y., Dong, J., Chi, Y., Zhou, Z., Ni, M., 2016. Energy and Exergy Analyses of Fluidized-Bed Municipal Solid Waste Air Gasification. Energy Fuels 30, $7629-7637$.

[83] Thamavithya, M., Jarungthammachote, S., Dutta, A., Basu, P., 2012. Experimental study on sawdust gasification in a spout-fluid bed reactor. Int. J. Energy Res. 36, 204-217.

[84] Tinaut, F. V, Melgar, A., Pérez, J.F., Horrillo, A., 2008. Effect of biomass particle size and air superficial velocity on the gasification process in a downdraft fixed bed gasifier. An experimental and modelling study. Fuel Process. Technol. 89, 1076-1089.

[85] Torres, E., Rodriguez-Ortiz, L.A., Zalazar, D., Echegaray, M., Rodriguez, R., Zhang, H., Mazza, G., 2020. 4-E (environmental, economic, energetic and exergetic) analysis of slow pyrolysis of lignocellulosic waste. Renew. Energy 162, 296-307.

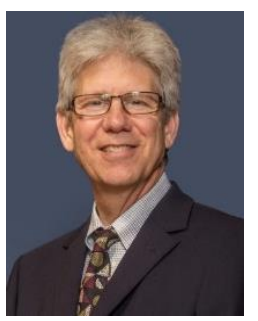

Dr. Marc A. Rosen is a professor of mechanical and manufacturing engineering at the University of Ontario Institute of Technology (Ontario Tech University), where he served as founding Dean of the Faculty of Engineering and Applied Science. He serves as Editorin-Chief of several journals, including Sustainability and Biofuels, ad he is an editor of Energy Conversion and Management. He has written numerous books, coauthored over 900 journal articles, and received over 70 research grants. His research topics include energy sustainability, polygeneration, district energy, efficiency improvement, energy, environmental impact assessment and reduction, exergy analysis, hydrogen energy and fuel cells, renewable energy, thermal energy storage, and thermodynamics. He has worked for Imatra Power Company in Finland, Argonne National Laboratory near Chicago, the Institute for Hydrogen Systems
[86] Ubando, A.T., Rivera, D.R.T., Chen, W.H., Culaba, A.B., 2019. A comprehensive review of life cycle assessment (LCA) of microalgal and lignocellulosic bioenergy products from thermochemical processes. Bioresour. Technol. 291, 121837.

[87] van der Heijden, H., Ptasinski, K.J., 2012. Exergy analysis of thermochemical ethanol production via biomass gasification and catalytic synthesis. Energy 46, 200-210.

[88] van Eck, N.J., Waltman, L., 2010. Software survey: VOSviewer, a computer program for bibliometric mapping. Scientometrics 84, $523-$ 538.

[89] Vitasari, C.R., Jurascik, M., Ptasinski, K.J., 2011. Exergy analysis of biomass-to-synthetic natural gas (SNG) process via indirect gasification of various biomass feedstock. Energy 36, 3825-3837.

[90] Wan, C., Yu, F., Zhang, Y., Li, Q., Wooten, J., 2013. Materia Balance and Energy Balance Analysis for Syngas Generation by a Pilot-Plant Scale Downdraft Gasifier. J. Biobased Mater Bioenergy 7. 690-695.

[91] Watson, J., Zhang, Y., Si, B., Chen, W.-T., de Souza, R., 2018 Gasification of biowaste: A critical review and outlooks. Renew. Sust. Energy Rev. 83, 1-17.

[92] Wu, Y., Yang, W., Blasiak, W., 2014. Energy and Exergy Analysis of High Temperature Agent Gasification of Biomass. Energies 7, $2107-2122$

[93] Wu, Z., Zhu, P., Yao, J., Zhang, S., Ren, J., Yang, F., Zhang, Z., 2020 Combined biomass gasification, SOFC, IC engine, and waste hea recovery system for power and heat generation: Energy, exergy, exergoeconomic, environmental (4E) evaluations. Appl. Energy 279,115794

[94] Wunderlich, J., Armstrong, K., Buchner, G.A., Styring, P., Schomäcker, R., 2021. Integration of techno-economic and life cycle assessment: Defining and applying integration types for chemical technology development. J. Clean. Prod. 287, 125021

[95] Yan, Q., Guo, L., Lu, Y., 2006. Thermodynamic analysis of hydrogen production from biomass gasification in supercritical water. Energy Convers. Manag. 47, 1515-1528.

[96] Zhang, Y., Li, B., Li, H., Zhang, B., 2012. Exergy analysis of biomass utilization via steam gasification and partial oxidation Thermochim. Acta. 538, 21-28.

[97] Zhang, Y., Xu, P., Liang, S., Liu, B., Shuai, Y., Li, B., 2019. Exergy analysis of hydrogen production from steam gasification of biomass: a review. Int. J. Hydrogen Energy 44, 14290-14302.

[98] Zhao, Z., Andre Situmorang, Y., An, P., Yang, J., Hao, X., Rizkiana, J., Abudula, A., Guan, G., 2021. A biomass-based small-scale power generation system with energy/exergy recuperation. Energy Convers. Manag. 227, 113623.

[99] Zhong, D., Zeng, K., Li, J., Yang, X., Song, Y., Zhu, Y., Flamant, G., Nzihou, A., Yang, H., Chen, H., 2021. 3E analysis of a biomass-toliquids production system based on solar gasification. Energy 217, 119408 .

near Toronto, and Ryerson University in Toronto. Dr. Rosen has served as president of the Engineering Institute of Canada and the Canadian Society for Mechanical Engineering. He is a fellow of the Engineering Institute of Canada, Canadian Academy of Engineering, Canadian Society for Mechanical Engineering, American Society of Mechanical Engineers, International Energy Foundation, and Canadian Society for Senior Engineers. Dr. Rosen has received numerous awards and honours, including an Award of Excellence in Research and Technology Development from the Ontario Ministry of Environment and Energy, the Engineering Institute of Canada's Smith Medal for achievement in the development of Canada, and the Canadian Society for Mechanical Engineering's Angus Medal for outstanding contributions to the management and practice of mechanical engineering. He received a distinguished scholar award from Ryerson University and a Mid-Career Award from the University of Toronto. 


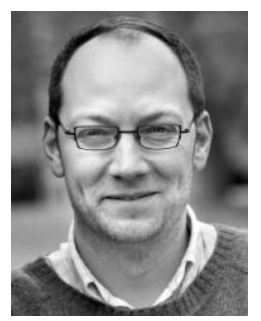

Bert F. Sels (1972), full professor at KU Leuven, obtained his Ph.D. in 2000 in the field of heterogeneous oxidation catalysis under the guidance of professor Pierre Jacobs. He was awarded the DSM Chemistry Award in 2000, the Incentive Award by the Belgian Chemical Society in 2005, and the Green Chemistry Award in La Rochelle in 2015. He is currently the director of the Centre for Sustainable Catalysis and Engineering (CSCE) at the Faculty of Bioscience Engineering at KULeuven, Belgium. His research activities encompass future challenges associated with the sustainable transition of industrial organic chemistry, focusing on the utilization of renewable carbon. He has more than 380 peer-reviewed papers, an h-index of 92, and more than 30000 citations (Google Scholar), and he wrote more than 30 patents. He is listed as a 'highly cited researcher' on the global Clarivate list (2021). His research expertise includes catalysis in biorefinery and biofactory processes, the design of hierarchically porous materials, spectroscopy and kinetics for mechanism clarification and active site identification. He was appointed member of the Research Council of the University. He is co-chair of the Catalysis Commission of the International Zeolite Association (IZA) and co-founder of the European Research Institute of Catalysis (ERIC). He is elected member of the European Academy of Sciences and Arts and Academia Europaea, visiting professor in the Chinese Academy of Sciences, international board member of ChemSusChem (Wiley), ChemCatChem (until 2021, Wiley), and currently associate editor of ACS Sustainable Chemistry \& Engineering (ACS). More details on Prof. Sels` research can be found at http://www.selsgroup.eu/

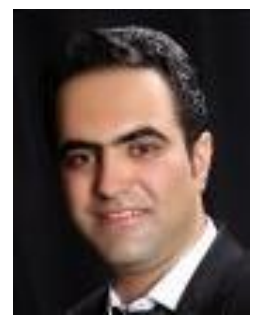

Hossein Shahbeig holds a Ph.D. degree in Chemical Engineering (Biotechnology) from the Tarbiat Modares University, Iran. His research interests primarily include renewable energies, biofuels, thermochemical conversion processes, and sustainability assessment. $\mathrm{He}$ is currently working as an Associate Researcher and has publications in precious journals such as Renewable and Sustainable Energy Reviews and Fuel. Hossein has worked in the petrochemical industry for seven years as a senior engineer in the field of QC\&QA.

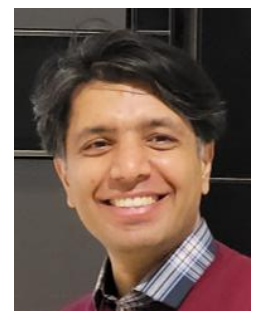

Alireza Shafizadeh (1985) received his B.Sc. and M.Sc. in Mechanics of Agricultural Machinery Engineering from the Isfahan University of Technology in 2008 and 2011, respectively. In 2013, Alireza joined the biomass and renewable energies industrial sector by establishing a company focusing on the thermochemical conversion of sugarcane bagasse biomass. In 2019, Alireza persuaded his education at a higher level and is currently a Ph.D. Student in Renewable Energies at the University of Tehran. The title of his Ph.D. thesis is "Modeling production and upgrading of bio-oil and bio-crude using machine learning techniques". His main research interests include biomass thermochemical conversion, machine learning application in biofuel production, and the application of high-tech catalysts and materials for biofuel production. 